\title{
ARMENIAN GARSHUNI: AN OVERVIEW OF THE KNOWN MATERIAL
}

\author{
HIDEMI TAKAHASHI \\ THE UNIVERSITY OF TOKYO
}

\begin{abstract}
This article presents a list of the manuscripts known to contain texts in Armenian written in Syriac characters (Armenian Garshuni), followed by a description of two newly discovered instances of such material (MSS Aleppo Syr. Orth. 61M and Mardin Chaldean 10), and an attempt at classification of the known Armenian Garshuni texts.
\end{abstract}

\section{INTRODUCTION}

If we leave aside instances of Armenian proper names and single Armenian words appearing in earlier Syriac texts and inscriptions, we know of only a relatively small number of manuscripts containing what may be called "Armenian Garshuni," i.e. Armenian material written in Syriac characters. The number of such manuscripts known to us, however, has been increasing in the past few years thanks largely to the digitisation of hitherto not so easily accessible manuscripts by the Hill Museum \& Manuscript Library (HMML).

It was by chance that I began working on Armenian Garshuni a few years ago, a move that can only be described as an act of folly given my almost total lack of competence in Armenian. Having encountered and become interested in the Armenian lexical 
material in MS Yale Syriac 9 during my six-month stay at Yale in 2009 within the framework of the Todai-Yale Initiative, I had the privilege of working with the late Professor Jos J. S. Weitenberg on an article on a part of that material which was published in 2010 11. ${ }^{1}$ Since then a good number of my Syrologist colleagues, mainly those working on the newly digitised manuscripts, have had the kindness to inform me of further instances of manuscripts containing materials in Armenian Garshuni.

I first present below a list of the manuscripts that are known to me at this moment to contain materials in Armenian Garshuni. This will be followed by a description of the materials which have been brought to my notice since the submission of two other articles on the subject which are now in the press, ${ }^{2}$ together with an attempt at classification of the known texts and a brief word on the significance of this material.

\section{MANUSCRIPTS KNOWN TO CONTAIN MATERIALS IN ARMENIAN GARSHUNI}

\section{A. Sixteenth Century}

(1) 1574-75: Birmingham University, Mingana, Syriac 44 (copied by Ephrem in Dayr al-Za'farān), fol. 132: Lord's prayer in

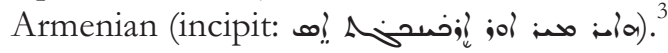

${ }^{1}$ Hidemi Takahashi \& Jos J.S. Weitenberg, "The Shorter SyriacArmenian Glossary in Ms. Yale Syriac 9," part 1 (Journal of the Canadian Society for Syriac Studies 10 [2010]): 68-83; part 2 (Hugoye: Journal of Syriac Studies 14:1 [2011]): 87-144.

2 Takahashi, "Armenisch-Garschuni (Armenisch in syrischer Schrift)," in Scripts beyond Borders. A Survey of Allographic Traditions in the Euro-Mediterranean World, ed. J. den Heijer, A. Schmidt \& T. Pataridze (Louvain: Peeters, forthcoming), and id., "Armenian Garshuni (Armenian in Syriac Script) and Its Users," in Syriac in Its Multi-Cultural Context, ed. H. Teule, E. Keser-Kayaalp, K. Akalin, N. Doru \& M. S. Toprak (Louvain: Peeters, forthcoming).

${ }^{3}$ See Sebastian Brock, "Armenian in Syriac Script," in Armenian Studies. Études arméniennes. In Memoriam Hä̈g Berbérian, ed. Dickran Kouymjian (Lisbon: Calouste Gulbenkian Foundation, 1986), 75-80. Text in Syriac characters and in transcription in Takahashi, "ArmenischGarschuni." 


\section{B. Seventeenth Century}

(2a) ca. 1658: Aleppo, Syrian Orthodox Archdiocese 61M, fol. $1-$ 126. Copied by Pilațos in Khartbert in 1643. The texts in the manuscript include: the Life of Mor Barșawmo $(1 \mathrm{v}-97 \mathrm{v})$; the Life of Mor Dimet (98r-103v); the story of a priest who committed murder and immediately repented $(104 \mathrm{r}-107 \mathrm{v})$; the Life of Simeon the Stylite $(107 \mathrm{v}-)$. There are marginal glosses in Armenian Garshuni, apparently in the hand of the copyist of the second part of the manuscript, on fol. $1 \mathrm{v}, 4 \mathrm{r}, 5 \mathrm{v}, 9 \mathrm{r}, 11 \mathrm{r}$, $11 \mathrm{v}, 18 \mathrm{r}, 36 \mathrm{v}, 48 \mathrm{v}, 50 \mathrm{r}, 51 \mathrm{r}, 65 \mathrm{v}, 104 \mathrm{r}, 107 \mathrm{v} .^{4}$

(2b) 1658: Aleppo, Syrian Orthodox Archdiocese 61M, fol. 133264. Copied by Ephrem [b. Ohanes], in the Monastery of Mor Abhay. Miscellanea, including: (i) canons of Bar Kepha and Bar Șalibi in Armenian Garshuni (fol. 251rv); and (ii) marginal glosses in Armenian Garshuni on fol. 133r-134r, 135r, 156v, $232 \mathrm{v}, 240 \mathrm{r}, 241 \mathrm{v}, 248 \mathrm{r}, 248 \mathrm{v} .^{5}$

${ }^{4}$ With thanks to Andrew Palmer, who is working on an edition of the Life of Mor Barsawmo, for bringing the Armenian material in this manuscript to my attention, as well as for his valuable comments on the paper, and to HMML for access to digital images of the manuscript. See further below.

${ }^{5}$ This part of the manuscript contains the following items. (1) $133 \mathrm{r}-$ 166r: Life of Mor Abhay (beginning missing), corresponding to Paulus Bedjan (ed.), Acta martyrum et sanctorum, vol. 6 (Paris/Leipzig: Harrassowitz, 1896): 561.11 (ولقاما -614.17; followed by the colophon by the copyist, the note by the author (Bedjan, 614.18-616.4), and a note on the propriety of Emperor Theodosius testing the saints' bones by fire. (2) 166r-168r: "from the commentary on the Gospel of Mark" (

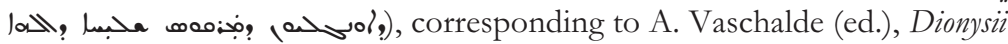
Bar Salibi Commentarii in Evangelia, II(1) (Paris 1931, repr. Louvain: Durbecq, 1953): 178.8-180.27. (3) 168r-169v: excerpts from Bar Șalibi’s

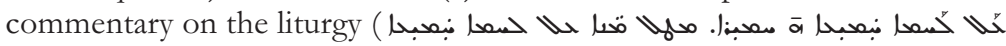

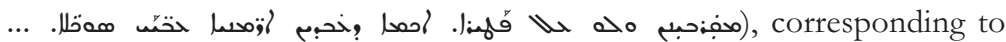
Hieronymus Labourt (ed.), Dionysius Bar Salïbì. Expositio liturgiae (Paris:

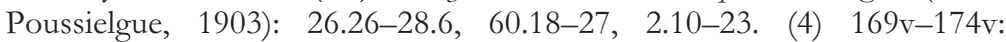
Patriarch John [bar Shushan], on the mystery of the salt, leaven and oil in

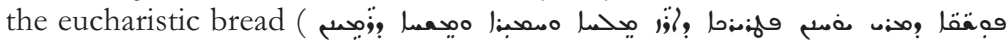
(حمنز); cf. H. Zotenberg, Catalogues des manuscrits syriaques et sabéens (mandaïtes) de la Bibliothèque nationale (Paris: Imprimerie nationale, 1874): 71 (Paris syr. 111, no. 17). (5) 174v-178v: "questions of the holy teachers" (مبa) Näa), with passages attributed to (a) Adday, (b) Jacob of 
(3) 1658-59: Harvard University, Houghton Library, Syriac 54, 371 folios. Copied by Bishop Ephrem bar Ohanes of Vank, in the Monastery of Mor Abhay, for Rabban Habib of Urhoy. SyriacArmenian lexicon based on the Lexicon of Bar Bahlul. ${ }^{6}$

Edessa, (c) Evagrius, (d) Ignatius of Antioch, (e) Gregory [Thaumaturgus], (f) Basil, (g) Gregory, (h) John Chrysostom, (i) Dionysius the Areopagite, (j) Jacob of Edessa (176r-), (k) Jacob of Edessa (177r-), (l) Severus, (m) John Chrysostom; cf. Zotenberg, Catalogues. 72 (Paris syr. 111, no. 19); items (d), (e), (h), (i), (k) and (m) also in a similar collection of antiArmenian polemic in MS Laur. or. 298, 140v-141r, published as an appendix in Otto Lichti, "Das Sendschreiben des Patriarchen Barschuschan an den Catholicus der Armenier" (Journal of the American Oriental Society 32 [1912]): 268-342, here 300-305 (nos. 5, 6, 7, 8, 11, 12).

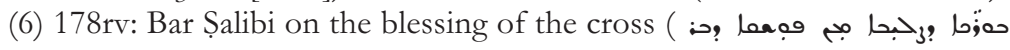
(ב $\boldsymbol{ح}_{3}$ ), corresponding to Labourt, Expositio: 79.23-30 (with the addition of

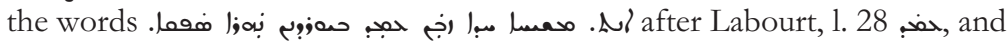

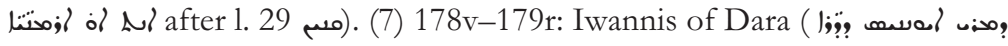

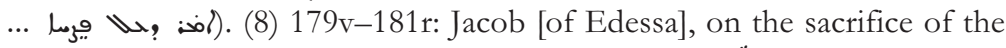

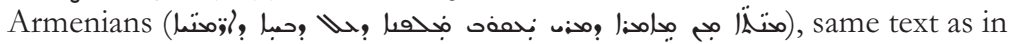
MS Laur. or. 298, 139r-141r, Lichti, “Sendschreiben”: 298-300. (9) 181v-

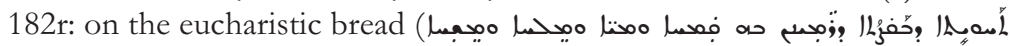

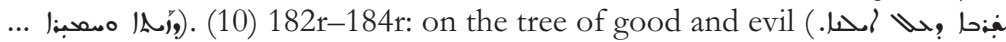

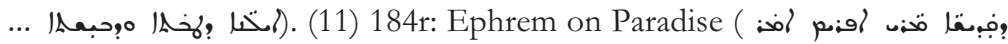

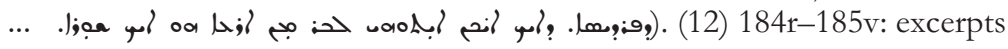
from Bar 'Ebroyo, Hudoye V.5 (on prayer), corresponding to Paulus Bedjan (ed.), Nomocanon Gregorii Barbebrai (Paris/Leipzig: Harrassowitz, 1898): 65.2-66.12, 63.7-64.2. (13) 185v-187r: mimro on the observance of

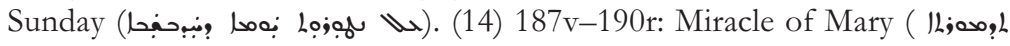

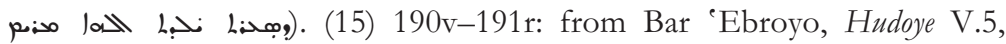
corresponding to Bedjan, Nomocanon: 66.13-67.12. (16) 191v: on the bad

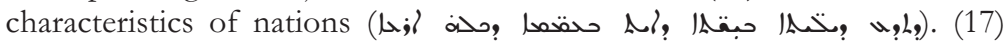

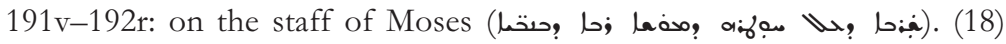
193v: same piece as (16). (19) 194r-199r: story of Barbara and Juliana (أمحبه| (20) 199v-224r: of

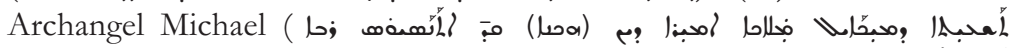

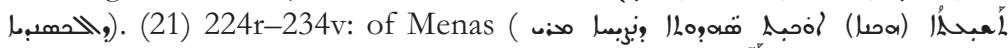

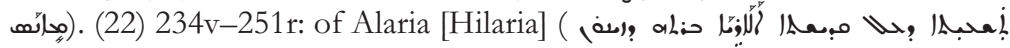
فححا.). (23) 251rv: canons of Bar Kepha and Bar Șalibi (see below). (24)

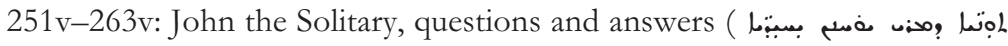
(حمةًم).

6 See D. S. Margoliouth, "The Syro-Armenian Dialect," Journal of the Royal Asiatic Society, 1898: 839-861, for a discussion of the material in this 
(4) 1665/6: Cairo, Franciscan Centre of Christian Oriental Studies, Syriac 11, vi +333 pages. Copied by deacon Malkeh ibn Nìqūdīmūs, apparently for Patriarch Ignatius Shukr-Allah, in Amid. Syriac-Arabic-Armenian lexicon (the originally ArabicSyriac lexicon of Elias of Nisibis, Kitäb al-tarjumān fì ta'lim lughat al-suryan, with Arabic and Syriac columns in the reverse order, and with the addition of Armenian entries in a third column). ${ }^{7}$

(5) 17th c.?: Yale University, Beinecke Rare Book \& Manuscript Library, Syriac 9. Miscellanea, including: (i) a Syriac-Armenian glossary (mostly verbs in their various forms, arranged alphabetically and apparently excerpted from the same lexicon as that represented in the Harvard manusript, p. 4-199); (ii) Syriac-Armenian glossary (excerpt from Elias' Kitäb al-tarjumān, chapter [ta'lim 28 , section $[b \bar{a} b] 2$, and chapter 29, with the addition of Armenian equivalents and without the Arabic headwords, p. 231-241); and (iii) marginal glosses in Armenian Garshuni on p. 200, 218, 229, 224, 241-243, 247, 248, 251$253,258,260,261,263,267-269,279,281,282,284 .^{8}$

manuscript; cf. Moshe H. Goshen-Gottstein, Syriac Manuscripts in the Harvard College Library. A Catalogue. Missoula: Scholars Press, 1979: 59-60; Ighnāțiyūs Afrām I Barșawm, Al-Lu'lu' al-manthūr fì tārìkh al-ulūm wa-l-ädāb al-suryaniyya (Holland [Glane/Losser]: Bar Hebraeus Verlag, 1987): 23; further discussion in Takahashi, "Armenisch-Garschuni."

7 See Sebastian Brock, "Catalogue des manuscrits syriaques, éthiopiens et arméniens du Centre d'Etudes Orientales Chrétiennes du Mouski, Le Caire. A) Syriac Manuscripts" (Studia Orientalia Cbristiana Collectanea 18 [1985]): 213-218, here 216-217, and id., "Armenian in Syriac Script." Further discussion in Takahashi, "Armenisch-Garschuni," and Ester Petrosyan, Yuhhplip \$puighuljuid Uhupuintpjnı\&nıu upuhumuilnn Syriac 11 tinultiqne dinuqhp punupuip

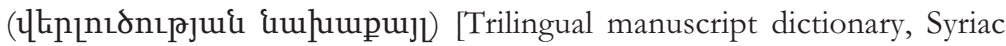
11, preserved at the Franciscan Centre in Cairo] (Graduation thesis, Yerevan State University, 2013).

${ }^{8}$ On the manuscript, see Leo Depuyt, "Classical Syriac Manuscripts at Yale University: A Checklist," Hugoye: Journal of Syriac Studies 9:2 (July 2006 [2009]): 173-188, here 176-177, 182; and H. Takahashi, "Also via Istanbul to New Haven - Mss. Yale Syriac 7-12," in Islamic Pbilosophy, Science, Culture and Religion: Studies in Honor of Dimitri Gutas, ed. D. Reisman \& F. Opwis (Leiden: Brill, 2012): 157-176, here 170-172. On the glossary on p. 231-241 of the manuscript, see the article cited in note 1 above. 
(6) 17th c.?: Mardin, Chaldean Cathedral 10 (81 Scher), fol. 8r: Trisagion in Armenian, among the renditions of the Trisagion in eight languages (Latin, Greek, Armenian, Georgian, Persian, Turkish, Arabic, Syriac). ${ }^{9}$ [See the Addendum on p. 109-110 below.]

\section{Eighteenth/Nineteenth Century}

(7) 1711/2: Vatican, Bibliotheca Apostolica Vaticana, Syr. 544. A manuscript mainly of the Syriac breviary (shbimo, 34v-96r), preceded and followed by prayers, readings etc., copied by deacon Ibrahim/Abrohom. ${ }^{10}$ (i) fol. 9v-12v: The heading on $9 \mathrm{v}$ announces a bo'utho of Jacob [of Sarug] (ILe حس ملم

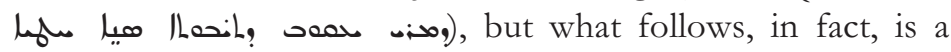
transcription in Armenian Garshuni of the standard formulas for renunciation of Satan, confession of faith, and confession of sins as found at the beginning of the Armenian breviary (zamagirk'). ${ }^{11}$ (ii) $13 \mathrm{r}-14 \mathrm{v}$ : Creed and Gloria in Armenian

${ }^{9}$ With thanks to Adam McCollum for bringing this material to my attention; cf. Adam McCollum, "Syro-Georgian Trisagion," http://hmml orientalia.wordpress.com/2013/10/24/syro-georgian-trisagion/. See further below.

10 See Arn[old] van Lantschoot, Inventaire des manuscrits syriaques des fonds Vatican (490-631) Barberini oriental et Neofiti (Vatican City: Biblioteca Apostolica Vaticana, 1965): 69. The copyist's name appears in Arabic on fol. 25v, 26r and 105r, and in Syriac on fol. 34v. Van Lantschoot dated the manuscript to "1711-1712" citing the notes on fol. 26v and 107r. The date on fol. 26v, however, which van Lantschoot seems to have read as “2022" (حصد, 1710/11 A.D.), is in a later note in a different hand from that of the main text and should be read as "2102" (حمد, 1790/1 A.D., cf. note 54 below). The only basis that we have for the date of the manuscript is therefore the note on fol. 107r, giving us the date "2023"

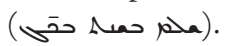

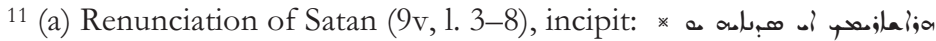
: محامُ ( $*$ : Armenian "uu" with abbreviation sign, standing for

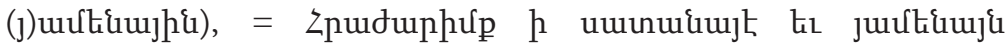
huuptnıpt<<化> anpuu. (b) Confession of faith $(9 \mathrm{v}, 1.9-11 \mathrm{r}, 1.11)$,

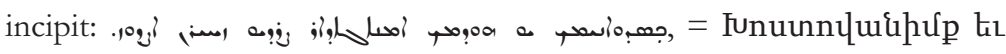

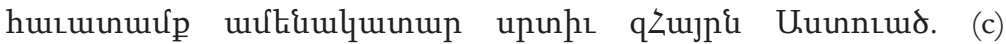

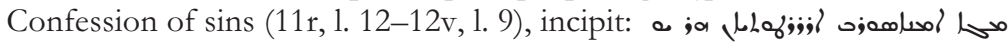

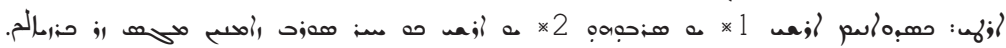


Garshuni. ${ }^{12}$ The manuscript also has notes in Armenian characters on fol. 9v, 13v, 14v, 17r, 19r, 21v, 22v (as numerals), $24 \mathrm{v}, 25 \mathrm{r}, 28 \mathrm{r}, 33 \mathrm{v}, 38 \mathrm{rv}, 42 \mathrm{v}, 43 \mathrm{r}, 45 \mathrm{r}, 46 \mathrm{v}, 50 \mathrm{r}, 52 \mathrm{r}, 56 \mathrm{r}, 58 \mathrm{r}$, $60 \mathrm{r}, 68 \mathrm{rv}, 70 \mathrm{v}, 72 \mathrm{v}, 74 \mathrm{v}$.

(8) 1746: Diyarbakı, Church of Yoldat Aloho (Meryem Ana) 74 (6/10, HMML DIYR00140). A manuscript of the order of baptism, copied by khūrī Yeshū' b. Ni'ma al-Qușūrānī for the Church of Yoldat Aloho in Amid, at the request of khūrī 'Abd al-Nūr b. Aṣlān al-Āmidī. On fol. 79r-79v, immediately before the final colophon, are the formulas in Armenian Garshuni for

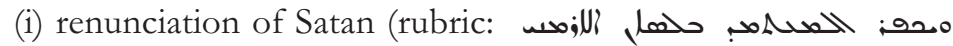

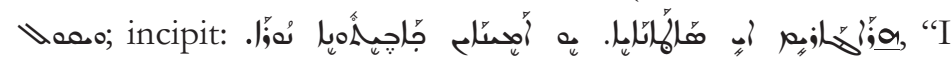
reject Satan and all his tricks ..."), and (ii) confession of faith (rubric: Veas incipit:

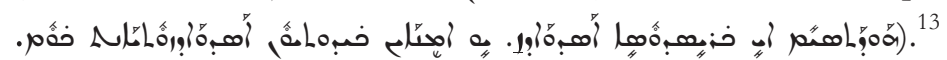

(9) 18th c.?: Dayr al-Za ‘farān 197 (HMML ZFRN 00197), fol. 98r:

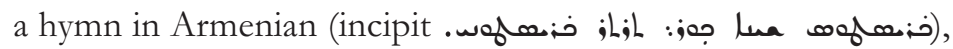
in a collection of hymns for Palm Sunday and Maundy

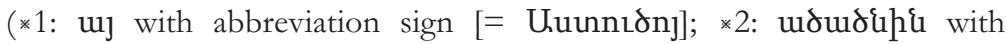
abbreviation sign [=Uuunnuudurduhi]; $-l m$ at the end in Arabic characters), = Utinuj uuftiuuntpp Eppnpnnıpteukq' Zop tis

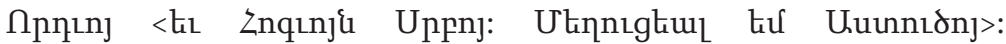

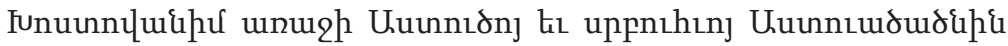

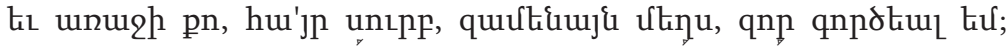
explicit: : - 0 ( $x$ : semkat here with a sign below resembling the cursive form of the

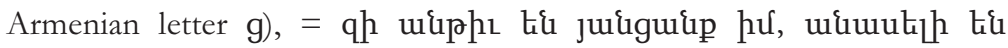

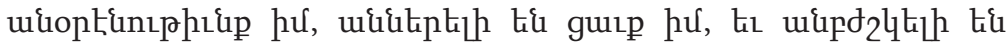
lthpp hu. <ufinuj Uuunnıonj:> Zujp unıpp. Cf. Žamagirk' (Kolkata: Pōłos Vijēnean, 1848): 1.4-6.26; Žamagirk' hayasteayc' S. eketec'woy (Vałaršapat, 1903; text reproduced online at http://titus.unifrankfurt.de/texte/etcs/arm/zamanak/zamant.htm): 5.2-10.5.

12 Text in Syriac and Armenian characters, with French translation, in Arn[old] van Lantschoot, "Un texte arménien en lettres syriaques," in Mélanges E. Tisserant, vol. 3, Studi e testi 233 (Vatican City: Biblioteca Apostolica Vaticana, 1964): 419-428.

${ }_{13}$ With thanks to Jean Fathi for bringing this material to my attention. 
Thursday in Syriac, Arabic, Turkish, Armenian and Persian, all of them in Syriac characters. ${ }^{14}$

(10) ca. 1800: Birmingham University, Mingana, Syriac 520, fol. 8v: same hymn. ${ }^{15}$

(11) 18/19th c.?: Birmingham University, Mingana, Syriac 184, fol. 89r: same hymn. ${ }^{16}$

(12) 18/19th c.: Diyarbakır, Church of Yoldat Aloho 232 (10/17, HMML DIYR 00244), fol. 27r-27v: hymn to Mary (heading:

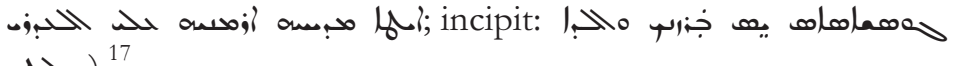
(م). $\left.{ }^{17}\right)^{17}$

\section{NEWLY DISCOVERED ITEMS}

\subsection{Aleppo, Syrian Orthodox Archdiocese 61M}

The main text in the first part (fol. 1-127) of MS Aleppo, Syr. Orth. 61M, which includes the lives of Mor Barșawmo, Mor Dimeț and Simeon the Stylite, was copied, according to the colophon at the end of the life of Mor Barșawmo on fol. 97v, in August 1954 A.Gr. (1643 A.D.) by Pilatos in the Church of Yoldat Aloho in Khartbert (Harput). The text breaks off in mid-sentence at the end of $127 \mathrm{r}$, and this is followed by a number of blank pages $(127 \mathrm{v}-$ 132v). The second part (fol. 133-264), which contains a large

14 With thanks to Adam McCollum for bringing this piece to my attention. Text in Syriac characters and in transcription in Takahashi, "Armenisch-Garschuni."

15 Alphonse Mingana, Catalogue of the Mingana Collection of Manuscripts, vol. 1 (Cambridge: Heffer, 1933): 957; cf. Brock, "Armenian in Syriac Script": 80. On the polyglot collection of hymns in Mingana 520 and 184 as a whole and on the Persian piece in particular, see Mauro Maggi \& Paola Orsatti, "Two Syro-Persian Hymns for Palm Sunday and Maundy Thursday," in The Persian Language in History, ed. M. Maggi \& P. Orsatti (Wiesbaden: Reichert, 2011): 247-285; on the Turkish piece, Peter Zieme, "An Overview of Garshuni Turkish," in Syriac in Its Multi-Cultural Context, ed. H. Teule, et al. (Louvain: Peeters, forthcoming).

${ }^{16}$ The presence of the Armenian piece is not mentioned by Mingana in his catalogue (col. 406), but see Maggi \& Orsatti, "Two Syro-Persian Hymns": 249.

${ }^{17}$ With thanks to Grigory Kessel for bringing this material to my attention. 
number of short pieces, was copied, as we learn from the numerous colophons in this part (fol. 163r-165r, 166r, 181r, 187r, 190r, 224r, 234v, 263v), ${ }^{18}$ in the spring of 1969 A.Gr. (1658 A.D.) by bishop Ephrem, aged seventy-five at the time (166r), in the Monastery of Mor Abhay in the region of Gargar (Gerger), also known as the Monastery of the Ladder. From the handwriting, and in view of other circumstances, there can be little doubt that this is the same person as the bishop Ephrem who copied the SyriacArmenian lexicon in MS Harvard Syriac 54, and who tells us in the colophon of that manuscript that he was aged seventy-seven upon completing it in the Monastery of Mor Abhay on 22nd August 1659. ${ }^{19}$

Scattered throughout both parts of the manuscript are marginal glosses, most of them giving the Armenian equivalents of the words found in the main text, and all of them apparently in the hand of the copyist of the second part of the manuscript. As a sample, the glosses in the part of the manuscript containing the Life of Mor Barsawmo are given below as they appear in the manuscript and in transcription, ${ }^{20}$ followed by the corresponding or related words in literary Armenian (unless indicated otherwise in Modern Western Armenian) and citations of some related entries among the lexicographical materials in MSS Harvard Syr. 54 and Yale Syr. $9 .^{21}$

18 We also learn from these colophons of the flooding of the Euphrates, which reached as far as the "fifth step" (bawqo) of the ladder leading to the monastery on 17th April 1658 (181r) and of a battle that took place between Aṣlan Pasha and the Kurds around Gargar (251r).

${ }^{19}$ Cf. Takahashi, "Armenisch-Garschuni," note 11. Ephrem seems to have been somewhat unsure of his age, since he reportedly tells us in the colophon of another manuscript of the lexicon of Bar Bahlul dated September 1657 that he was seventy-six at the time (Ignatiyus Afrem dbet Barșawm [ed. Ignațiyus Zakkay I d-bet 'Iwāṣ], Srițoto d-Omid w-Merdo. Makbtūūtāt Ämid wa-Mārdīn. Omid \& Mardin Manuscripts [Ma'arrat Șaydnāyā: Dayro d-Mor Afrem Suryoyo, 2008]: 88).

20 For the transcription system used here, see Takahashi \& Weitenberg, "The Shorter Syriac-Armenian Glossary," part 2: 90-92.

${ }^{21}$ For the entries from the Yale manuscript cited only by page, line and item numbers, see Takahashi \& Weitenberg, "The Shorter SyriacArmenian Glossary," part 2. 


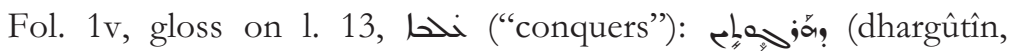
"conquest") - i.e. dharg- + abstract noun ending -ûtîn (-nıphıf); dialect unuhplitl "to conquer" - Yale 232.3.2, 238.15.1 (dhargâ); Yale 179.22.1: نحسم:; Harv. 275v

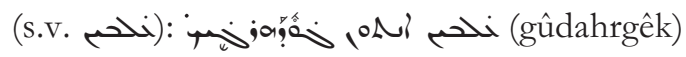

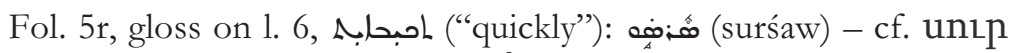

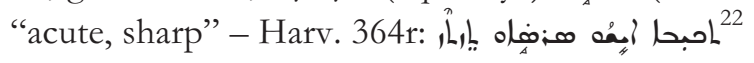

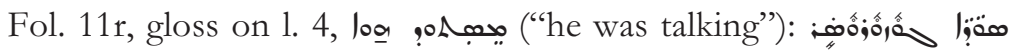
(gûzûrûsir) - ln qnıpgłp (3 sg. imperf. of qnıpg $k_{1}$, qpnıg $k_{L}$

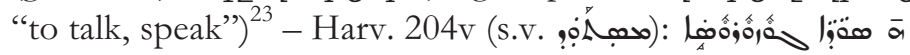

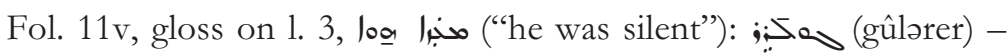
4L jnkp (3 sg. imperf. of $1 n k_{1}$ "to keep silent") - Harv. 206r

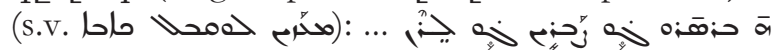

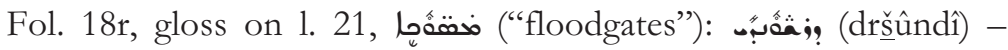

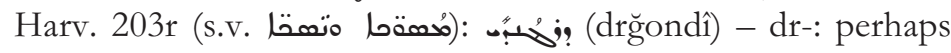
Arm. nnin / Pers. dar "door, gate"

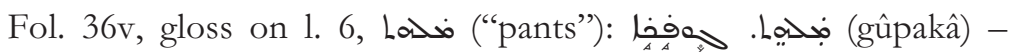

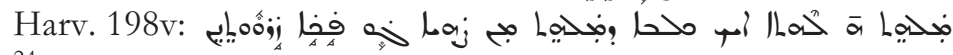
24

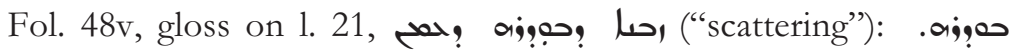

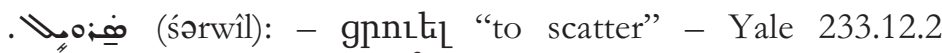

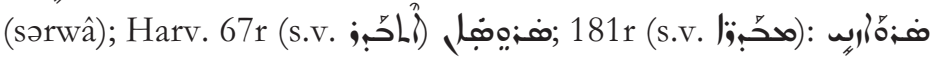
Fol. 50r, gloss on 1. 23, بمده: (“that they flatter"):

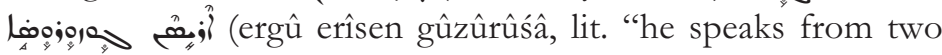

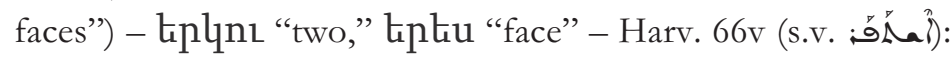

22 teztez: cf. Takahashi \& Weitenberg, “The Shorter Syriac-Armenian Glossary," part 2: no. 241.6.3.

${ }^{23}$ On the realisation of the classical/literary Armenian stressed "-e-" as "-i-" in the dialect represented here, see Takahashi \& Weitenberg, "The Shorter Syriac-Armenian Glossary," part 1: 76 (section 5.3.2 (a)).

24 żarwûtenen "from thirst": cf. dupuu "thirst." 
(gû șalosanâ, "he beguiles") 25

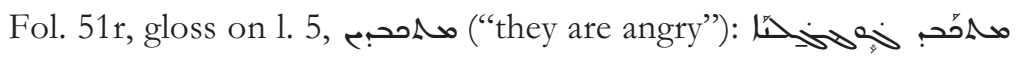

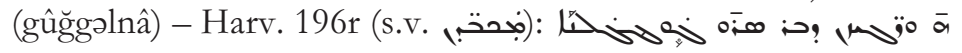

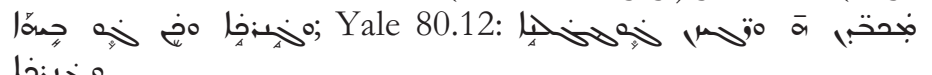
ن

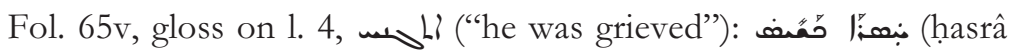
kašîs). - Arab. hasra "grief, sorrow"; pų kig "he drew" (3 sg. pret. of purki "to pull, draw") - Harv. 68r (s.v. "in

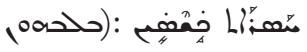

Although there are some differences which should be noted (e.g. in the position of the vowel in the stem of dhargûtin/ gûdahrgêk, and in the way the third consonant is represented in dršûndî/drğondî̀), it will be seen that there is generally a close agreement between the glosses and the related material in the Harvard manuscript in the choice of vocabulary and in the way the words are represented in Syriac characters. This, of course, is not surprising, seeing that these glosses and the Harvard manuscript were most probably copied by the same person. Ephrem is likely to have had access to the exemplar of the Harvard manuscript when he copied the second half of the Aleppo manuscript and probably also wrote these glosses in the spring of 1658 , just some months before he started copying the Harvard manuscript in September 1658, not for his own use but for the use of Rabban Habib in Aleppo. ${ }^{26}$ Further investigation will be needed to determine whether the glosses are (1) based on the lexicon, (2) based on Ephrem's own knowledge of Syriac and Armenian, or (3) simply copied from the exemplar of our manuscript (unlikely in the first half of the manuscript where the glosses and the main text are due to different people). If the second of these is the case, the possibility might be considered that Ephrem is, in fact, the author (translator into Armenian) of the Harvard lexicon, or that he at least had a hand in its redaction.

25 Cf. Takahashi \& Weitenberg, "The Shorter Syriac-Armenian Glossary," part 2: no. 236.2.2 and note 37.

${ }^{26}$ Ephrem had made another copy of Bar Bahlul's lexicon in 1657. Whether that manuscript also contained the Armenian material is not stated in the catalogue (cf note 19 above). 
Besides these glosses, the manuscript also contains one continuous passage in Armenian Garshuni, which is preceded by the following canon in Syriac, forbidding monks to become godfathers (fol. 251r). ${ }^{27}$

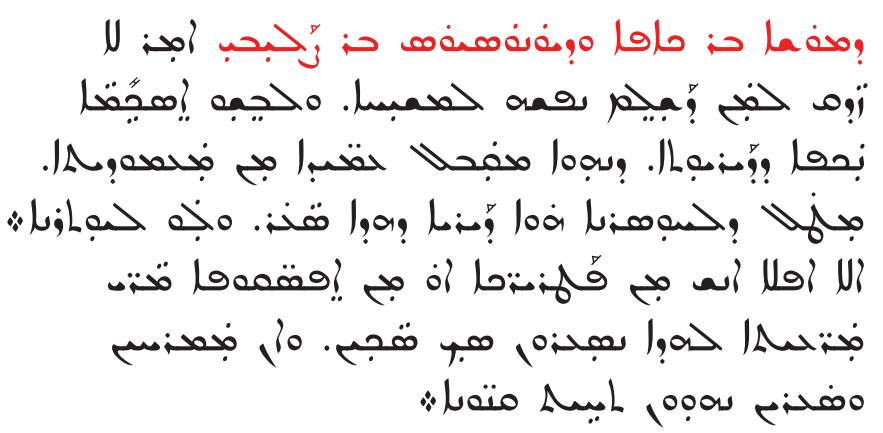

[Canons] of Moses bar Kepha and Dionysius bar Șalibi. He said: One who has surrendered himself/his soul to Christ, and has put on the chaste habit of monastic life must not receive the baptised from the baptismal font, ${ }^{28}$ because (this) will be to the detriment of the monk who does so, and not to (his) profit. ${ }^{29}$ Let no one even among the patriarchs and bishops who are in charge of dioceses do so at all. If they dare to do so, let them be under the canons.

The Armenian part reads as follows (fol. 251r-251v):

${ }^{27}$ On the canon of Moses bar Kepha forbidding monks to become godfathers, see Arthur Vööbus, Syrische Kanonessammlungen. I. Westsyrische Originalurkunden, 2 vols. (Louvain: Sécretariat du Corpus CSO, 1970): 1, A, 228, n. 7 (on other similar canons, ibid., B, 286, n. 17, 292, n. 12, 351, n. 12, 364, n. 17).

${ }^{28}$ Receiving the newly baptised child from the baptismal waters symbolised becoming a godfather, with the social obligations this entailed (with thanks to Andew Palmer for this clarification).

${ }^{29}$ The text as it stands, "because a monk who does so is to detriment," does not make good sense. I translate supplying $l$ - (or $d$-) before dayräya in the light of the Armenian version that follows. 


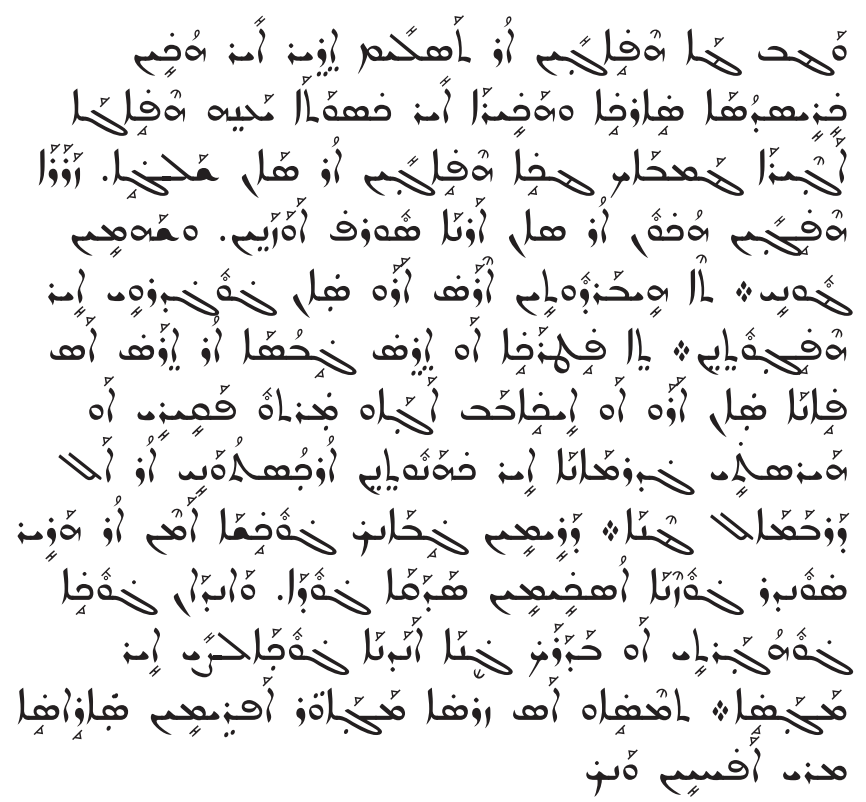

It has not so far been possible to elucidate all the elements in this passage, but the first part of it appears to be a translation, or paraphrase, of the canon quoted in Syriac, while the latter part prescribes a penance similar to those found in the penitential canons of Bar Salibi. ${ }^{30}$ The text is given below in transliteration, followed by an attempt at translation and explanation of the individual words. ${ }^{31}$

(1) wağb ğâ hepaḡin or taslîm erēr îr hokîn Kirîsdosa śârkâ whakîrâ $\hat{i r}^{32}$ kswatâ ya'neh hepâgâ aḡērâ ğambâk ğkâ hepâgîn or sân šalgâ, zararâ hepâgîn hokûn or s(a)n arnâ sûrp awazanēn, w-šahmîn ğûnî.

${ }^{30}$ For similar canons attributed to Bar Șalibi enjoining penance with genuflexions and almsgiving, see Henricus Denzinger, Ritus Orientalium, Coptorum, Syrorum et Armenorum, in administrandis sacramentis. 2 vols. (Würzburg: Stahel, 1863-64): I.493-500; cf. Vööbus, Syrische Kanonessammlungen. I. Westsyrische Originalurkunden, 1, B: 405-439.

${ }^{31}$ With thanks to Thomas Carlson for some useful suggestions in solving the puzzle.

32 ir: in margin. 
"A monk who has surrendered his soul into Christ's hands, and put on his habit (?), i.e. has become a monk, must not have a child. For the monk who lifts a godchild (?). It is harmful (?) for the soul of the monk who takes a godchild from the holy baptismal font, and he has no gain."

wağb: "it is necessary" (?), cf. Arab. wağaba, wäğib; cf. Harv. 124r:

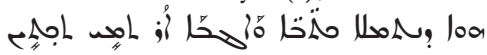

ğâ: "now" (interjection) (?), cf. Yale 240.6.2

hepaḡin: "for the monk" [gen./dat., w(ith) art(icle)], cf. Harv. 105v,

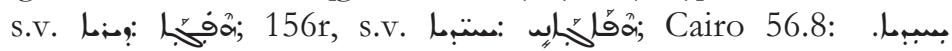

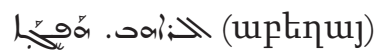

or: "who" (rel. pron.) and "that" (conj.) (np)

taslîm: "surrender," Arab. taslim

erēr: probably nptep (past ptc. of pitul "to do"); for the past ptc.

in -Łp, cf. "hakîrâ" and "aḡērâ" below

îr: "his" (hp)

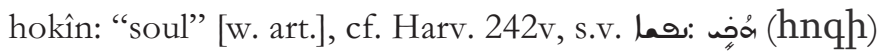

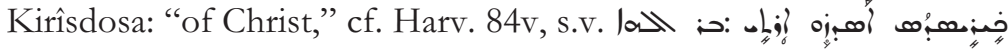

(Pphuunu), here apparently with genitive ending in -a (uuj)

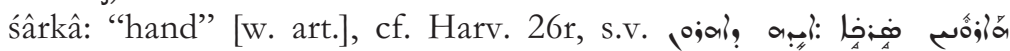
$(\text { (̇tinp })^{33}$

w-: "and," evidently representing Syr. o, rather than Arm. Gi (cf.

Yale 240.6.3)

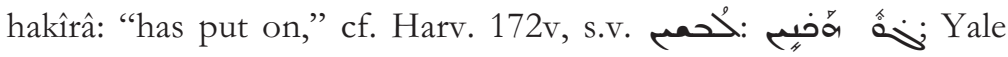

235.2.2 (huiqtip t; huuqull "to put on")

ya'neh: "i.e.," Arab. ya'ni (cf. Yale 240.23.1, 241.8.2)

aḡērâ: "has become," cf. Yale 240.11.3 (aḡîrâ) (knkp t)

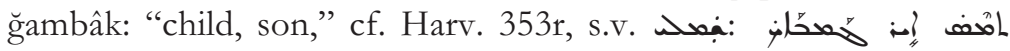

مسنف: of and the corresponding sentence in the lexicon of

33 On the realisation of classical Armenian "-e-" as "-a-" before liquids, see Takahashi \& Weitenberg, "The Shorter Syriac-Armenian Glossary," part 1: 76 (section 5.3.2 (c)). 
Bar Bahlul: مصنج (from quúpultip "suckling"?)

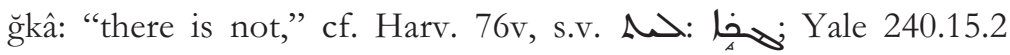
(negative particle $2+$ luuj)

sân: "infant, pupil" (uư)

šalgâ: “carries, lifts,” cf. Yale 237.13.3: لَّهَ (class. Arm. 2ujultiud)

zararâ: probably Arab. darar "harm, detriment" (cf. Yale 234.1.1), with $\mathrm{E}$ "he/it is"

hokûn: "for the soul" [gen./dat., w. art.]

arnâ: "takes," cf. Yale 233.23.1 (unqut; unqukl "to take")

sûrp: "holy" (untpp)

awazanēn: "from the pool, baptistery" [abl., w. art.], cf. Harv. 206v,

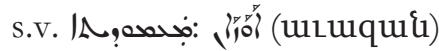

šah: "profit, gain" (2uh)

-mîn: indefinite article (Upqu)

ğûnî: "does not have" ( $(2+$ nullp; nuluhl "to have, possess"); cf.

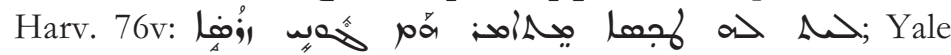
233.14 .2

(2) tê hîbardûtîn eraś araw sân gûgdrwî îr hepagûtenen.

"If he was serving as a subdeacon (?) (when?) he took a godchild, he is deprived of his monastic status."

tê: "if, or" (pL)), cf. Yale 240.18.4, 240.20.2

hîbardûtîn: "subdiaconate" (?), cf. hpluykiptun "servant, subdeacon"

eraś: “(he) did," cf. Yale 239.9.3 (npuul, dialect npuug)

araw: "(he) took" (unuil)

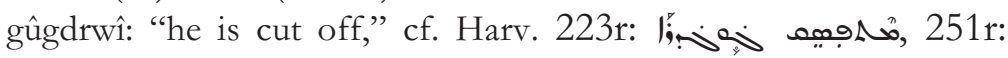

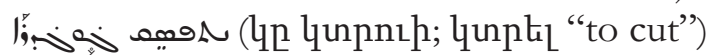

hepagûtenen: "from the monkhood" [abl., w. art.]

34 Rubens Duval (ed.), Lexicon syriacum auctore Hassano Bar-Bablule (Paris: Leroux, 1901): 1987, 1. 19-20. 
(3) tê pațrakâ aw ereś gabosâ or eraś as pânâ sân araw aw îkâbab aḡaw martû paqîî̀ aw hayrstî gdrmânâ îr $\mathrm{k}(\mathrm{a})$ hanûtenen or kostowanî or al darbamâl ğenâ.

"If it is the patriarch or a bishop who did this, [i.e.] took a godchild, or became a sponsor for [the child of] someone, poor or rich, he is deprived of his priestly status. Who affirms that he will not do so again (?)",35

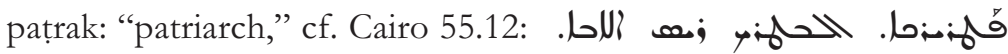
خجه The form of the word is closer to Arab. batrak and Turk. patrik than to literary Armenian uquinphupp.

-â: article (n) or "it is" (L)?

aw: "or," Syr. of

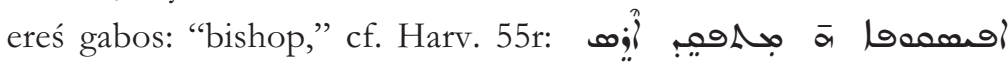

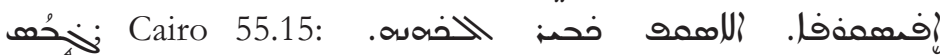

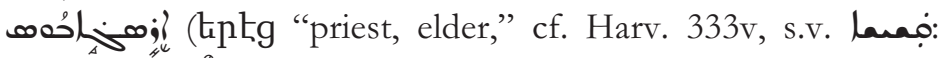

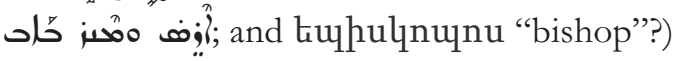

as: "this," cf. Yale 240.2.3 (uuju, uu) pânâ: "word, thing" [w. art.] (?) (puu)

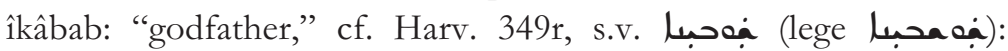
إخفاحِاد "cf. qupuhuujp "godfather"; and upuu "grandfather")

aḡaw: "(he) became," cf. Yale 240.11.2 (tinur).

martû: "for a man" [gen./dat.] (Uuupn)

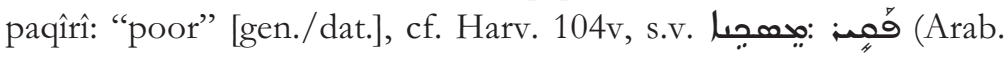
faqir)

hayrstî: "rich" [gen./dat.] (hupntuun)

gdrmânâ: "has been cut off"; probably "gdr-" as in "gûgdrwî" above, with the past participle ending "-man,,"36 and $\mathrm{h}$ "(he) is"

35 The words "who affirms..." are probably to be taken with what follows rather than with what precedes in spite of the punctuation of the manuscript.

36 Cf. Margoliouth, "The Syro-Armenian Dialect": 850-851; Takahashi \& Weitenberg, "The Shorter Syriac-Armenian Glossary," part 1: 79 (5.4(b)). 
kahanûtenen: "from the priesthood" [abl., w. art.] (puhuifuujnıphiq)

kostowanî: "confesses," cf. Yale 232.4.2, 236.19.1 (hunuunnuluî,; hunuunnluluhl "to confess").

al: "also, too" (?) (ui)

darbamâl: darb-: related to unupptup "different" (?); -mal: cf. Yale 241.9.1 (megmal, utly u' uL “another”)

ğenâ: "does not do" (?) (¿ nॄ̊t)

(4) darîmîn gabânk gûkašâ amen or harîr śûndr gûzenâ oskîmîn sadaqâ gûdâ, wândân gûkâ gûhoḡartî aw badarak genâ anadnâ gûkâalṣ̂i îr maḡaśâ.

"carries fetters for one year, does a hundred genuflexions every day, gives a gold (coin) as alms, then (?) ... (?) or offers a mass, is then absolved from his sins."

darîmîn: "a year" (unuph, with indef. article)

gabânk: "chains" (पuuuuulup)

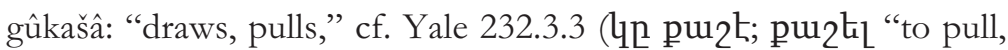
draw")

amen: "all, every" (uutki)

or: "day" (op)

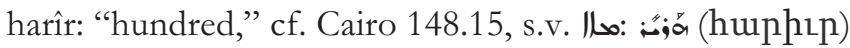

sûndr: "knee" (onılup)

śûndr gûzenâ: "makes genuflexions," cf. Harv. 327r, s.v. متبر

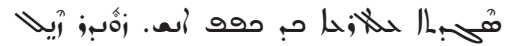

oskîmîn: "a gold [coin]" (nulh "gold," with indef. article)

sadaqâ: "alms," Arab. șadaqa

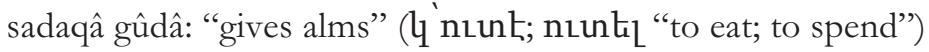

wândân: "and then" (?), cf. "anadnâ" below

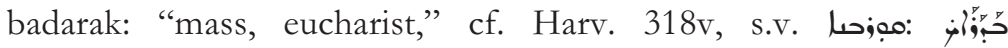

(uwunupuiq)

genâ: "he does," cf. Yale 239.10.1 (प' 'nut)

anadnâ: "then," cf. Yale 240.8.2, 241.4.3 (uj氏 uuntin).

gûkâlș̣̂: "he is delivered, absolved," no doubt from Arab. khallaṣa,

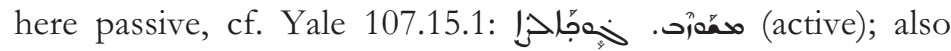
Yale 235.9.3 
maḡaśâ: "from the sins" [abl., w. art.] (Ulınp)

(5) tmeśâw as $\operatorname{zr}(0) s ́(\hat{a})$ maḡâwor aprēmîn śârâśâ m(o)ry apḥ(a)yîn wank.

"This piece (?) was completed by the hand of the sinner Ephrem (in?) the Monastery of Mor Abhay."

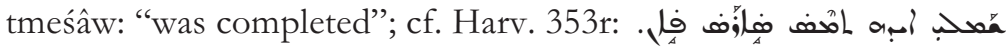

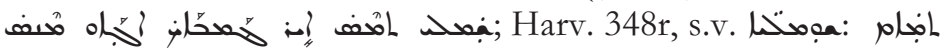
"oli Yale 237.17.2; apparently from Arab. tamma "to complete," tamām "end"

zrośâ: "talk, story" [w. art.] (?) (qpnjg)

maḡâwor: "sinner" (ukinuınn)

aprēmîn: "of Ephrem” [gen., w. art.]

śârâŝâ: "by the hand” (đ̌knp, class. đłłnq, gen./dat./abl. pl.

¿thuug)

wank: "monastery" (luuqu)

\subsection{Trisagion in MS Mardin, Chaldean Cathedral 10}

[See the Addendum on p. 109-110 below.]

This piece is unique in that it is the only one among the items listed above which is in the East Syrian script. The manuscript was judged to date from the seventeenth century by Scher. ${ }^{37}$ Adam McCollum has kindly informed me that the manuscript itself unfortunately provides no indication of its provenance or of a more precise date. ${ }^{38}$ The part containing the renditions of the Trisagion follows after the verbal paradigms (⿻上丨) which are listed as the first item in the manuscript by Scher and end at the top of folio 8r. The pieces in the eight languages are introduced by

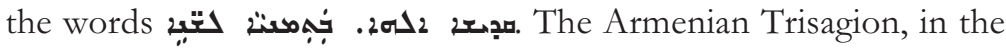

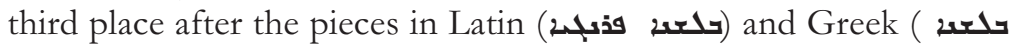

37 Addaï Scher, "Notice sur les manuscrits syriaques et arabes conservés dans la bibliothèque de l'évêché chaldéen de Mardin," Revue des bibliothèques 18 (1908): 64-95, here 87.

38 Personal communication, 24th October 2013. 


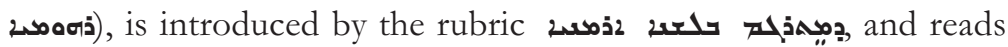
as follows:
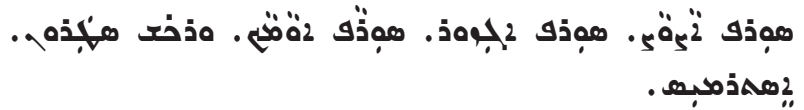

The first three phrases, though containing some clear errors of transcription, can be recognised as the main part of the Armenian Trisagion, Unıpp Uuunnuud, untpp li hqop, untpp lu uudurh (surp Astuac, surp ew hzor, surp ew anmah). The beginning (WR KŚ-) and the end (MYS) of the remaining words have some resemblance to the beginning and the end of the formula usually added to the Trisagion in the Armenian Orthodox tradition, $\mathrm{n} p$

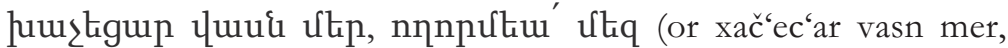
ołormea mez, "who was crucified for us, have mercy on us"). The parts in between do not correspond so closely to the rest of the formula, but the cluster STRWN does include some letters that one might expect to see in a rendition of "xač'ec'ar vasn" (perhaps originally صel sim.), and it is conceivable that the cluster 'STR (2nos) arose from a corruption of the cluster of letters representing "ołor-" (jo_.o2?). ${ }^{39}$ If this is correct, and the Syriac text above does represent the usual Armenian Orthodox form of the Trisagion, we must assume some serious corruption of the text in the course of its transmission. The level of corruption is, in fact, equalled in some of the other pieces on the same page. The pieces there in Latin and Georgian, ${ }^{40}$ which are languages less likely to have been familiar to Syriac copyists, present a similar level of difficulty in one's attempt to reconcile the Syriac transcription with

${ }^{39}$ A number of other formulas are added to the Trisagion in the Armenian tradition according to the liturgical season. None of these formulas fit the text we have any better (with thanks to Karen Hamada for the information on these additions).

40 The Latin piece there, in fact, is not a translation of the Trisagion, but the opening words of the popular Easter hymn, "O filii et filiae, Rex

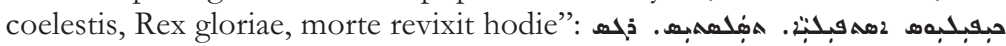
(the first "rex" is missing altogether in the Syriac transcription). For this version of the hymn, probably the original version, with the word "revixit" instead of the more usual "surrexit," see Amédée Gastoué, "L'O filii, ses origines, son auteur," La Tribune de Saint Gervais 13 (1907): 82-90, here 89. 
the presumed original, while the Turkish and Arabic pieces, in languages usually better known to Syriac copyists, are less problematic. ${ }^{41}$

As a similar instance of a polyglot Trisagion, we know of a collection in Greek, Syriac, Georgian, Persian, Arabic, Kurdish ("Median") and Turkish, all in Armenian characters, preserved in MS Yerevan, Matenadaran 7117, the manuscript known for its role in the rediscovery of the Caucasian Albanian alphabet, which was copied from an older manuscript brought in around 1442 from the Crimea at Mecop'avank' (to the north of Arčěš, Turk. Erciş, north of Lake Van), ${ }^{42}$ as well as in a copy of that manuscript made at the Monastery of the Mother of God of Barijor in Xizan (Turk. Hizan, to the southeast of Bitlis, south of Lake Van) in 1580 and once in the possession of $\mathrm{H}$. Kurdian, ${ }^{43}$ and in MS Matenadaran 4618

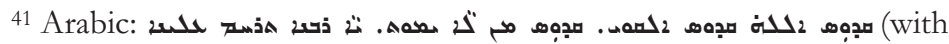
tarahham, no doubt a calque on Syriac etrahham; a form current in Mardin Arabic according to George Kiraz, personal communication, 30th Oct. 2013); Turkish: 2in modern Turkish orthography: "ar1 Tanr1, ar1 güçlü, ar1 olmaz, rahmat bizim üs $<\mathrm{t}>$ üne eyle," with thanks to Prof. Peter Zieme for his suggestion on the interpretation of the last part).

42 A. Šanidze, "Novootkrytyj alfavit kavkazskix albancev i ego značenie dlja nauki," Izvestija Instituta jazyka, istorii i material'noj kul'tury imeni akademika I. Ja. Marra Gruitinskogo filiala Akademii Nank SSSR 4 (1938): 162 (with photographic reproductions of the Trisagion texts, as well as of the different alphabets, on the plates between pages 16 and 17; with thanks to Grigory Kessel for the assistance in obtaining a copy of this article); cf. D. N. MacKenzie, "The Language of the Medians," Bulletin of the School of Oriental and African Studies 22:2 (1959): 354-355 (with thanks to Prof. Peter Zieme for bringing this article to my attention). On the manuscript, see Robert H. Hewsen, "On the Alphabet of the Caucasian Albanians," Revue des études arméniennes N.S. 1 (1964): 427-432; Jost Gippert, Wolfgang Schulze, Zaza Alexidze \& Jean-Pierre Mahé (eds.), The Caucasian Albanian Palimpsest of Mt. Sinai, vol. 1 (Turnhout: Brepols, 2008): xix-xx, II-1-2.

${ }^{43}$ H. Kurdian, "The Newly Discovered Alphabet of the Caucasian Albanians," Journal of the Royal Asiatic Society 88 (1956): 81-83. The manuscript is now presumably with the Mechitarists in Venice (see Bernard Coulie, Répertoire des bibliothèques et des catalogues de manuscrits arméniens [Turnhout: Brepols, 1992]: 226). 
(undated). ${ }^{44}$ These Trisagions accompany lists of the letters of the Greek, Syriac, Latin, Georgian, Caucasian Albanian, Coptic and Arabic (Kufic) alphabets. According to Prof. Jost Gippert, the alphabet lists must go back at least to the ninth century, the last period when the knowledge of the Caucasian Albanian alphabet is likely to have been current. ${ }^{45}$ The Trisagion collection, in which the Syriac version is transcribed according to the West Syrian

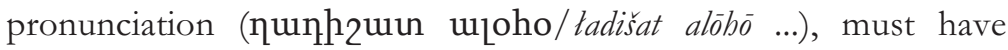
originated separately from, and most probably later than, the alphabet lists, where the names given to the Syriac letters reflect the Classical/East Syrian pronunciation (e.g. quuरl/gaml, nul/dal, puị/k'ap', juun/lasd [corruption, no doubt, of juưn/lamd]), but it too must have been in existence at the latest by the mid-fifteenth century when MS Matenadaran 7117 was copied. The text in the Mardin manuscript, on the other hand, cannot have originated before around 1500 given the inclusion there of the Latin hymn "O filii et filiae," if one is correct in ascribing that hymn to the Franciscan friar Jean Tisserand (d. ca. 1497), ${ }^{46}$ and if that Latin piece was not added to the versions of the Trisagion at a later date. It is not impossible that the idea of creating the polyglot Trisagion collection preserved in the Mardin manuscript was, in fact, inspired by the Armenian-character collection, which was in circulation in the sixteenth century in areas close to, if not within, those inhabited by Syriacs, ${ }^{47}$ although the major discrepancies between the Mardin

44 Andrea Schmidt, "Arménien et syriaque," in Arménie : la magie de l'écrit [exposition, Marseille, Centre de la vieille charité, 27 avril-22 juillet 2007], ed. C. Mutafian (Paris: Somogy, 2007): 345-348, here 345, 347. The text of the part visible on the photograph on p. 345 (the versions of the Trisagion in Greek, Syriac and Georgian, and the first four words of the Persian version) is essentially identical to that in Matenadaran 7117. Cf. Takahashi, "12.2. Armeno-Syriac," in George Anton Kiraz, Țürāṣ Mamllā: A Grammar of Syriac Language, vol. 1. Orthography (Piscataway: Gorgias Press, 2012): 325-326.

45 Oral communication, 9th Nov. 2013.

${ }^{46}$ Cf. note 40 above and the article by Gastoué cited there.

47 On the two Armenian monasteries mentioned above and their locations, see Michel Thierry, Répertoire des monastères arméniens (Turnhout: Brepols, 1993): 94 (no. 521), 15 (no. 68); Robert H. Hewsen, Armenia. A Historical Atlas (Chicago: The University of Chicago Press, 2001): 209 (map 199, A2, C1). 
text and the Armenian-character text in the wording of the Arabic, Persian and Turkish versions (i.e. in the languages where there were no standard translations of the Trisagion for ecclesiastical use) $)^{48}$ indicate that the Syriac-character versions cannot simply have been transcribed from the Armenian-character versions.

\section{ARMENIAN GARSHUNI MANUSCRIPTS: A CLASSIFICATION}

The Armenian Garshuni texts that we know of today might be classified into the following groups on the basis of their dates and their purposes.

\section{(1) Seventeenth-Century Lexica and Glosses}

The bulk of the Armenian Garshuni material that we have today is contained in the three lexicographical manuscripts (nos. 3, 4, and 5 in the list above). Of the three, the Harvard and Cairo manuscripts were copied in the latter half of the seventeenth century, and the same is probably also the case for the Yale manuscript. The Harvard manuscript was copied by Bishop Ephrem bar Ohanes, a native of the village of Vank near Gargar, in the Monastery of Mor Abhay in the same region. The Cairo manuscript was copied in Amid, but its copyist Malkeh ibn Niqudimus was also a native of Vank. The origin of the Yale manuscript is uncertain, but this manuscript too is likely to come from the Monastery of Mor Abhay. The copies of the lexica in these manuscripts, together with the Syriac-Armenian glosses in the Yale manuscript and those by Ephrem in MS Aleppo Syr. Orth. 61M (no. 2), can therefore be seen as the product of the same particular community. We know from other sources that the region around Gargar was home to a good number of Syrian Orthodox clerics in the sixteenth and seventeenth centuries who themselves or whose relatives bore Armenian names, ${ }^{49}$ and it is therefore quite likely that there was a

${ }^{48}$ For transcriptions of the Persian, Arabic and Turkish, as well as Kurdish, versions in Matenadaran 7117, see MacKenzie, "The Language of the Medians."

49 Further details in Takahashi, "Armenisch-Garshuni," and id., "Armenian Garshuni (Armenian in Syriac Script) and Its Users"; cf. Hubert Kaufhold, "Notizen zur späten Geschichte des BarșaumōKlosters" (Hugoye: Journal of Syriac Studies, 3/2 [2000 (2010)]): 223-246. 
community there which, though Syrian Orthodox in religious allegiance, was largely Armenian speaking by the time these manuscripts were produced.

In connection with the linguistic situation of the community around Gargar, we might also take note here of the instance of an Armenian manuscript bearing a Syriac colophon. MS Paris, Bibliothèque nationale, arménien 137, is a manuscript of Armenian theological works by the thirteenth-century Armenian vardapet Vahram, copied in the Gargar region in 1584 A.D. by someone calling himself Grigor/Krikor in Armenian. The main colophon of the manuscript, in which the Syrian Orthodox patriarch (David/Dawidshah) is named along with the Armenian vardapet in Gargar, is written in Syriac. In it the copyist, once a candidate for the Syrian Orthodox bishopric of Gargar, tells us that he took the pains to learn Armenian specifically for the purpose of reading and copying Vahram's work. ${ }^{50}$ What he means by "learning Armenian" may be learning to read and write in literary Armenian rather than learning to speak it. Be that as it may, the manuscript is in itself a precious record of the cultural (and theological) exchange between the Syriacs and Armenians in the Gargar region in the sixteenth century, and if the statement in the colophon can be understood to mean that the copyist Gregory had also to learn to speak Armenian, this may be considered to hint at a process in which the Syrian Orthodox community in the Gargar region became increasingly Armenian-speaking between the sixteenth and seventeenth centuries. This process of gradual Armenisation may also be what is indicated by the fact that the village later usually known as "Vank" (i.e. Armenian for "Monastery") evidently still appears as "Dayro/Deyro" in the administrative records of the sixteenth century, ${ }^{51}$ although this piece of evidence too should not

50 See Frédéric Macler, Mosaïque orientale (Paris: Geuthner, 1907): 3338 ("Notice syriaque d'un manuscrit arménien (1584)"); cf. id., Catalogue des manuscrits arméniens et géorgiens de la Bibliothèque nationale (Paris: Leroux, 1908): 74; Raymond H. Kévorkian \& Armèn Ter-Stépanian, Manuscrits arméniens de la Bibliothèque nationale de France. Catalogue (Paris: Bibliothèque nationale de France, 1998): 486. I thank Linda Wheatley Irving for bringing this item to my attention.

${ }^{51}$ Mehmet Taştemir, XVI. Yǚyılda Adıyaman Behisni, Hısn-ı Mansur, Gerger, Kâhta). Sosyal ve iktisadî tarihi (Ankara: Türk Tarihi Kurumu Basimevi, 1999): 80, and map no. 4. 
be pressed too far seeing that the village is regularly mentioned under both names in the colophons of seventeenth-century

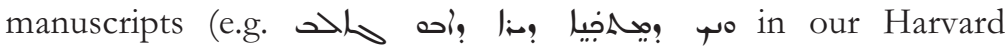
manuscript, and or in the Cairo manuscript).

The Armenian language of the Syriac-Armenian lexica and the glosses is not literary Armenian, but clearly reflects the language as spoken in the area where these lexica were produced and copied, with its phonetic, lexical and morphological peculiarities and, as may be seen also in the examples given above, with a significant number of loanwords mainly from Arabic. On phonological and morphological grounds, the dialect can be identified as a member of Dialect Group 5, a branch of Western Armenian once spoken in areas including Malatya, Diyabakır and Urfa. ${ }^{52}$ The orthographical system used in these manuscripts allows a relatively accurate representation of the sounds of Armenian through the use of special diacritical points. The Harvard, Aleppo and Yale manuscripts share a very similar system of transcription, while the system in the Cairo manuscript is somewhat different and is also less consistent. Of the three lexicographical manuscripts, the Harvard and Cairo manuscripts were copied by natives of the Gargar region for use by those living outside of this area. The Yale manuscript, to judge from its size and the writing, was probably intended for the personal use of the copyist.

\section{(2) Eighteenth-Century Liturgical Texts}

MSS Vatican Syr. 544 (no. 7) and Diyarbakır, Yoldat Aloho 74 (no. 8 ) were both copied in the first half of the eighteenth century. The Armenian Garshuni material that we find in these manuscripts consists of set liturgical formulas, and the language used is literary Armenian, in Western Armenian pronunciation. There is at least one case of non-standard pronunciation being reflected in the transcription, namely in the transcription of the " $\mathrm{h}$ " of the verb orbneal ("to praise") as "s" in the Vatican manuscript; ${ }^{53}$ this may reflect the way the word was actually pronounced even in the

52 See Takahashi \& Weitenberg, "The Shorter Syriac-Armenian Glossary," part 1.

${ }^{53}$ Van Lantschoot, "Un texte arménien": p. 424, 1. 2, 10, 13. The verb regularly appears in the form or 5 n- in the manuscripts of the SyriacArmenian lexica. 
liturgy at the time. The orthographical system used in these manuscripts, similar to, but with some divergences from, the system used in the Harvard, Yale and Aleppo manuscripts, allows for a relatively accurate representation of the sounds of Armenian. Given their placement at the end of a manuscript of the rite of baptism, the formulas in the Diyarbakir manuscript were probably intended for use by Syrian Orthodox clergy in administering the sacrament to Armenian speakers. The two texts there are fully vocalised, allowing them to be used also by those not conversant in Armenian. In the Vatican manuscript, the use of abbreviations in Armenian characters within the Armenian Garshuni texts and the presence of notes in Armenian characters throughout the manuscript indicate that the copyist was capable also of reading and writing Armenian in Armenian characters. The incompletely vocalised Armenian Garshuni texts there will have been intended for the use of someone who knew Armenian, probably the copyist himself, and, if van Lantschoot is correct in identifying the deacon Ahrun who later owned the manuscript as the copyist's son, ${ }^{54}$ perhaps also members of his own family.

\section{(3) Linguistic Specimens}

Of the remaining items in the list above, the Lord's Prayer in Mingana 44 (no. 1) stands somewhat apart from the rest in its sixteenth-century date. The inaccuracies in the transcription suggests that the copyist himself knew little Armenian, and the fact that an equally inaccurate transcription of the Latin "Pater noster" is found on the reverse side of the same folio suggests that the text was copied as an item of curiosity and as a specimen of the

54 Van Lantschoot, Inventaire: 69. On fol. 34v, the colophon " aحم

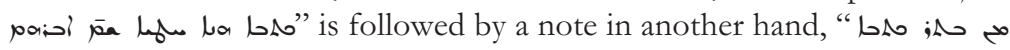
pa wa Lallowed by the name "Ahron" in Armenian characters (uhpni). The note on fol. 145v, on which van Lantschoot's statement about the relationship between the two is presumably based, is unfortunately barely legible in the black-and-white image of the manuscript at my disposal. On fol. 26v, we find another note by deacon

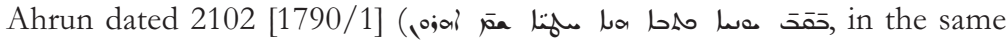
hand as the second hand on $34 \mathrm{v}$, cf. note 10 above), while on fol. $143 \mathrm{r}$ is

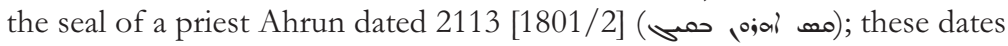
seem somewhat late for the son of a copyist working in 1711/2. 
language. The same is likely to be the case with the Trisagion in the Mardin manuscript (no. 6), if not when the text was originally written down in Syriac characters, at least when it was copied by the scribe of the Mardin manuscript. A possible connexion in the origin of the Syriac-character Paternosters in the Mingana manuscript and the Trisagion collection in the Mardin manuscript is, in fact, suggested by the similarity in the way the word "hodie" is misrepresented in the Latin pieces in both manuscripts (ti; Mingana, تجo.2 Mardin). It is needless to say that, given the nature of the texts in these two cases, the language the transcription is intended to represent is literary Armenian, even if we seem to have some reflexes of the colloquial pronunciation in the transcription of the "Our Father" in Mingana 44. The pronunciation represented in the Mingana manuscript is that of Western Armenian. With the Mardin Trisagion the brevity of the text and the inaccuracies in the transcription make it difficult to determine which variety of Armenian the transcription is intended to represent. The representation of the "p" of "surp" and "c" of "astuac" by unvoiced $\boldsymbol{s}$ and $\mathbf{s}$ suggests an Eastern variety, although it is to be noted that the "p" of "surp," preceded by a liquid, is also usually represented by $\rightarrow$ (and $\dot{\theta}$ ) in the manuscripts of our SyriacArmenian lexica and glosses. ${ }^{55}$

\section{(4) Popular Hymns}

The language, on the other hand, of the Armenian piece in MS Diyarbakır, Yoldat Aloho 232 (no. 12) is evidently colloquial and is certainly not classical Armenian, as may be seen from its very first line, where we find the Ottoman Turkish epithet "Vâlide Sultan," usually used of the mother of the reigning Sultan, applied to Mary. This appears also to be the case with the piece in the multilingual hymn collection (nos. 9-11). The origin of this multilingual hymn collection that also includes pieces in Arabic, Turkish and Persian remains unclear, but it may have been intended for use in liturgical celebrations which were attended by the representatives of different churches, as well as non-Christian dignitaries. If these

55 So, for example, in the passage at MS Aleppo Syr. Orth. 61M, fol. $251 \mathrm{r}-251 \mathrm{v}$, quoted above; similarly in the colophon of the Harvard manuscript, as well as in the body of the lexicon in that manuscript (fol.

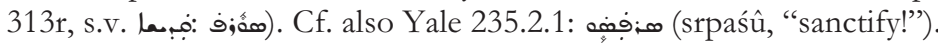


manuscripts really were used in such settings, the fact that the Armenian pieces in both the Diyarbakir manuscript and the multilingual hymn collection are largely unvocalised would suggest that the users of these manuscripts, even if they were not Armenian speakers, were familiar enough with the words of these relatively short hymns, no doubt from hearing them, to be able to sing them without the aid of vowel signs. The variety of Armenian represented in the hymn in Yoldat Aloho 232 is Western, as is indicated by the transcription of the obstruents in

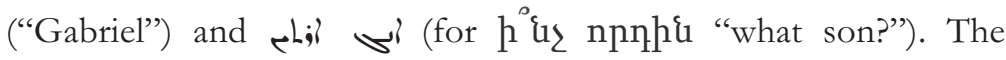
language of the hymn in the multilingual collection, on the other hand, will be Eastern Armenian, if one is correct in interpreting ; $\mathbf{i} \mathbf{j} \mathbf{L}$ and بـ, respectively, as untpuntp "priest" and uupn "man," and if the tet of فم فم represents an unvoiced "t."

\section{CONCLUDING REMARKS}

We might briefly consider here the material described above in the light of the "working definition" of Garshuni presented to us by Aaron Butts at the beginning of the Hugoye symposium on Garshunography at which this paper was originally presented, namely that "Garshuni is the practice of writing a language not in the writing system that is socio-linguistically associated with the language in question but in a writing system that is sociolinguistically associated with a different language or different languages."

What is important in this definition is the emphasis on the sociolinguistic aspect of the phenomenon. Unlike, for example, the Arabic language and writing system, the Armenian language and writing system were almost exclusively associated from the beginning with a particular ethnic and religious community, while the Syriac language and writing system, although it was not so at the beginning, had, by the time the texts described above were copied, become closely associated with certain religious communities, so much so that the two major groups using the Syriac language and writing system had come to develop distinct varieties of that writing system which often served as a mark of their religious identity.

The members of the two ecclesiastical communities with which we are mainly concerned here, the Armenian Orthodox and the 
Syrian Orthodox, frequently lived side by side. That geographical proximity, along with the perceived similarity of their "monophysite" faiths and the similar circumstances in which they lived under Muslim rule, would often give rise to the need for the two communities to distinguish themselves all the more from each other. This helps in part to explain the relative rarity of the materials in Armenian Garshuni. There would have been a certain reluctance on the part of the members of the two communities that often regarded the other community as rivals and heretics to use, or to be seen to be using, the language of the other. Paradoxically, it might also help explain why someone like Ephrem, the copyist of our Aleppo and Harvard manuscripts, felt the need to represent what was probably his mother tongue not in the writing system associated with that language but in the writing system associated with his own ecclesiastical community. There may, of course, be another simpler and more practical reason, namely that Ephrem and those like him, trained in Syrian Orthodox schools and monasteries, had no opportunity to learn to read and write in the Armenian alphabet, ${ }^{56}$ but it is also possible that what Ephrem was attempting to do was to provide the language he spoke with a new writing system that was not tainted by its association with a heretical church, and it is probably no coincidence, when viewed in this regard, that the part of the Aleppo manuscript copied by

${ }^{56}$ That there were Syriac scribes and scholars capable of writing Armenian in the seventeenth century may be gathered from the occasional glosses and notes in Armenian characters that we find in Syriac manuscripts from the period. An instance that has recently caught my eyes is that of a double note of a visit in Armenian and Arabic Garshuni by Elias of Khartbert dated 1928 A.Gr. (1616/7), found on the penultimate page of a copy of the lexicon of Elias of Nisibis (Aleppo, Syr. Orth. [Mar Jirjis] 123(L), manuscript copied by Daniel in 1523/4, probably in the Monastery of Mor Abhay who is invoked along with Mary in the colophon): tu uluupduifu utinunp (sic). un Enhuj humuhu. Enhuuj: huunpplingh: ("I, the unworthy sinner, Elias the priest (?), Elias of Khartpert," between columns);

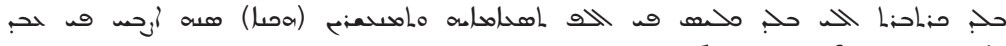

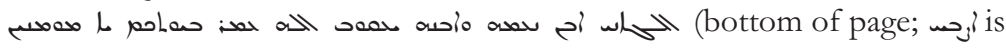
probably to be understood in a double sense, as numeral "1928" and Arab. as baba "he appeared (to), met"). 
Ephrem contains a selection of works directly or indirectly condemning the liturgical practices of the Armenians. ${ }^{57}$

As has been shown above, the corpus of Armenian Garshuni materials we have available to us today includes some different groups of items, and each of these groups will be of interest in different contexts. The most important group is no doubt that of the lexicographical manuscripts. The Armenian vocabulary found in these lexica is that of a particular dialect, and we have in them an amount of material more or less equalling the amount of material found in Arabic in the large lexica of Bar Bahlul and Elias of Nisibis. These manuscripts, when edited and appropriately indexed, may be expected to provide much valuable material for research in Armenian lexicography and dialectology. An in-depth study of the materials contained in these lexicographical manuscripts, as well as the rest of the Armenian Garshuni corpus, may also be expected, especially when taken in conjunction with other source materials, to give us some important new insights into the history of the contact between the Syriacs and Armenians, as well as the larger sociolinguistic environment surrounding them, where languages such as Arabic, Turkish and Kurdish were also in play.

As was stated at the beginning, the amount of material available to us in Armenian Garshuni is relatively small, but the corpus is, for the moment at least, a growing one. The rate at which new materials have been found in the newly digitised and catalogued manuscripts in the past few years suggests that we may expect to find more similar materials among the hitherto unexamined manuscripts, while the fact that some new materials have also been found among the manuscripts catalogued in the past (nos. 6 and 11) indicates that some materials that have escaped the eyes of the cataloguers may still await discovery also in the better known collections.

\section{ADDENDUM}

Shortly before the present article went online, Grigory Kessel kindly alerted me to the fact that the same text with the versions of the Trisagion as found in MS Mardin, Chaldean Cathedral (CCM) 10 is also present in another manuscript now in the same location, CCM 398 (olim Diyarbakır, Archevêché chaldéen 95 Scher; copied

${ }^{57}$ See note 5 above (especially the items (3)-(9) mentioned there). 
in 1583 A.D. by the monk/priest Joseph in the Monastery of John the Egyptian), fol. $243 \mathrm{v}-244 \mathrm{v} .{ }^{58}$ The Armenian version of the Trisagion is represented there (fol. 244r) by the same clusters of letters as in CCM 10, but with some variation in the vocalisation.

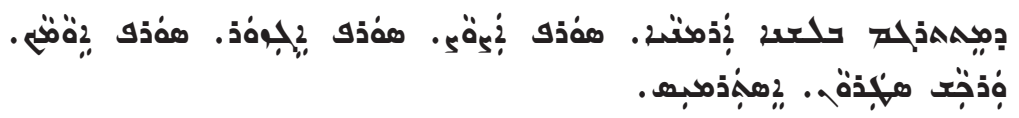

One major difference between the texts in CCM 10 and CCM 398 is that in the latter we have not only the first stanza of the Latin hymn "O filii" but also five of the subsequent stanzas, ${ }^{59}$ followed by the Latin version of the Trisagion ("Sanctus Deus"). It is hoped that we shall have the opportunity to present a more detailed description and discussion of the material in this manuscript in the near future.

\section{BIBLIOGRAPHY}

Barșawm, Ighnātịyūs Afrām I. Al-Lu'lu' al-manthūr fì tārīkh al-culūm wa-l-ädāb al-suryāniyya. Holland [Glane/Losser]: Bar Hebraeus Verlag, 1987.

Barșawm, Ignațiyus Afrem I d-bet (ed. Ignațiyus Zakay I d-bet 'Twāṣ). Srițoto d-Omid w-Merdo. Makbtūtāat Ämid wa-Mārdīn. Omid \& Mardin Manuscripts. Ma'arrat Șaydnāyā: Dayro d-Mor Afrem Suryoyo, 2008.

Bedjan, Paulus (ed.). Acta martyrum et sanctorum, vol. 6. Paris/Leipzig: Harrassowitz, 1896.

Bedjan, Paulus (ed.). Nomocanon Gregorii Barhebrai. Paris/Leipzig: Harrassowitz, 1898.

${ }^{58}$ Cf. Addai Scher, "Notice sur les manuscrits syriaques et arabes conservés à l'archevêché chaldéen de Diarbékir", Journal asiatique 10e sér. 10 (1907): 331-362, 385-431, here 397 (item nos. 27 and 28).

59 The stanzas present in CCM 398 correspond to stanzas 1, 2, 3, 5, 6 and 8 of the version considered to be original by Gastoué (see notes 40 and 46 above). In comparison with the text presented by Gastoué, the Latin text underlying the Syriac-character transcription must have had the variant "stetit plorans latrix Christi" for "venit plorans Mater Christi" in the second stanza, and "tange latus" for "vide latus" in the sixth. 
Brock, Sebastian. "Catalogue des manuscrits syriaques, éthiopiens et arméniens du Centre d'Etudes Orientales Chrétiennes du Mouski, Le Caire. A) Syriac Manuscripts.” Studia Orientalia Christiana Collectanea 18 (1985): 213-218.

Brock, Sebastian. "Armenian in Syriac Script." In Armenian Studies. Études arméniennes. In Memoriam Hä̈g Berbérian, ed. Dickran Kouymjian. Lisbon: Calouste Gulbenkian Foundation, 1986: 75-80.

Coulie, Bernard. Répertoire des bibliothèques et des catalogues de manuscrits arméniens. Turnhout: Brepols, 1992.

Denzinger, Henricus. Ritus Orientalium, Coptorum, Syrorum et Armenorum, in administrandis sacramentis. 2 vols. Würzburg: Stahel, 1863-64.

Depuydt, Leo. "Classical Syriac Manuscripts at Yale University: A Checklist." Hugoye: Journal of Syriac Studies 9:2 (2006 [2009]): 173-188.

Duval, Rubens (ed.). Lexicon syriacum auctore Hassano Bar-Bablule. Paris: Leroux, 1901.

Gastoué, Amédée. "L'O filii, ses origines, son auteur." La Tribune de Saint Gervais : bulletin mensuel de la Schola Cantorum 13 (1907): 8290 .

Gippert, Jost, Wolfgang Schulze, Zaza Alexidze \& Jean-Pierre Mahé (eds.). The Caucasian Albanian Palimpsest of Mt. Sinai, vol. 1. Turnhout: Brepols, 2008.

Goshen-Gottstein, Moshe H. Syriac Manuscripts in the Harvard College Library. A Catalogue. Missoula: Scholars Press, 1979.

Hewsen, Robert H. "On the Alphabet of the Caucasian Albanians." Revue des études arméniennes N.S. 1 (1964): 427-432.

Hewsen, Robert H. Armenia. A Historical Atlas. Chicago: The University of Chicago Press, 2001.

Kaufhold, Hubert. "Notizen zur späten Geschichte des BarșaumōKlosters." Hugoye: Journal of Syriac Studies 3:2 (2000 [2010]): 223246.

Kévorkian, Raymond H., \& Armèn Ter-Stépanian (avec le concours de Bernard Outtier et de Guévorg Ter-Vardanian). Manuscrits arméniens de la Bibliothèque nationale de France. Catalogue. Paris: Bibliothèque nationale de France, 1998. 
Kurdian, H. "The Newly Discovered Alphabet of the Caucasian Albanians." Journal of the Royal A siatic Society 88 (1956): 81-83.

Labourt, Hieronymus (ed.). Dionysius Bar Salïbi. Expositio liturgiae (textus). Paris: Poussielgue, 1903.

Lichti, Otto. "Das Sendschreiben des Patriarchen Barschuschan an den Catholicus der Armenier." Journal of the American Oriental Society 32:3 (1912): 268-342.

MacKenzie, D. N. "The Language of the Medians." Bulletin of the School of Oriental and African Studies 22:2 (1959): 354-355.

Macler, Frédéric. Mosaïque orientale. Paris: Geuthner, 1907.

Macler, Frédéric. Catalogue des manuscrits arméniens et géorgiens de la Bibliothèque nationale. Paris: Leroux, 1908.

Maggi, Mauro, \& Paola Orsatti. "Two Syro-Persian Hymns for Palm Sunday and Maundy Thursday." In The Persian Language in History, ed. M. Maggi \& P. Orsatti. Wiesbaden: Reichert, 2011: $247-285$.

Margoliouth, D. S. "The Syro-Armenian Dialect." Journal of the Royal Asiatic Society, 1898: 839-861.

McCollum, Adam. "Syro-Georgian Trisagion." On hmmlorientalia. http://hmmlorientalia.wordpress.com/2013/10/24/syrogeorgian-trisagion/.

Mingana, Alphonse. Catalogue of the Mingana Collection of Manuscripts, vol. 1. Cambridge: Heffer, 1933.

Petrosyan, Ester. Guhpptip \$puighuljui

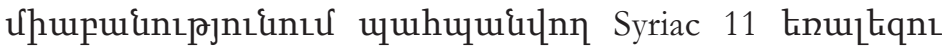

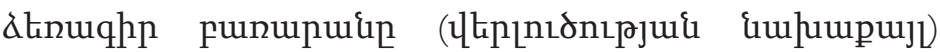
[Trilingual manuscript dictionary, Syriac 11, preserved at the Franciscan Centre in Cairo]. Graduation thesis. Yerevan State University, 2013.

Scher, Addai. "Notice sur les manuscrits syriaques et arabes conservés à l'archevêché chaldéen de Diarbékir." Journal asiatique 10e sér. 10 (1907): 331-362, 385-431.

Scher, Addaï. "Notice sur les manuscrits syriaques et arabes conservés dans la bibliothèque de l'évêché chaldéen de Mardin.” Revue des bibliothèques 18 (1908): 64-95. 
Schmidt, Andrea. "Arménien et syriaque." In Arménie : la magie de l'écrit [exposition, Marseille, Centre de la vieille charité, 27 avril-22 juillet 2007], ed. C. Mutafian. Paris: Somogy, 2007: 345-348.

Šanidze, A. "Novootkrytyj alfavit kavkazskix albancev i ego značenie dlja nauki." Iqvestija Instituta jazyka, istorii $i$ material'noj kul'tury imeni akademika I. Ja. Marra Gruzinskogo filiala Akademii Nauk SSSR 4 (1938): 1-62.

Takahashi, Hidemi. "11.3. Syro-Armenian" and "12.2. ArmenoSyriac." In George Anton Kiraz, Tūrrạs Mamllā: A Grammar of Syriac Language, vol. 1. Orthography. Piscataway: Gorgias Press, 2012: 298-304, 325-326.

Takahashi, Hidemi. "Also via Istanbul to New Haven - Mss. Yale Syriac 7-12." In Islamic Philosophy, Science, Culture and Religion: Studies in Honor of Dimitri Gutas, ed. David Reisman \& Felicitas Opwis. Leiden: Brill, 2012: 157-176.

Takahashi, Hidemi. "Armenisch-Garschuni (Armenisch in syrischer Schrift)." In Scripts beyond Borders. A Survey of Allographic Traditions in the Euro-Mediterranean World, ed. J. den Heijer, A. Schmidt \& T. Pataridze. Louvain: Peeters, forthcoming.

Takahashi, Hidemi. "Armenian Garshuni (Armenian in Syriac Script) and Its Users." In Syriac in Its Multi-Cultural Context, ed. H. Teule, E. Keser-Kayaalp, K. Akalin, N. Doru \& M. S. Toprak. Louvain: Peeters, forthcoming.

Takahashi, Hidemi, \& Jos J.S. Weitenberg. "The Shorter SyriacArmenian Glossary in Ms. Yale Syriac 9," part 1, Journal of the Canadian Society for Syriac Studies 10 (2010): 68-83; part 2, Hugoye: Journal of Syriac Studies 14:1 (2011): 87-144.

Taştemir, Mehmet. XVI. Yǚyzlda Adıyaman (Behisni, Hısn-ı Mansur, Gerger, Kâhta). Sosyal ve iktisadî taribi. Ankara: Türk Tarihi Kurumu Basımevi, 1999.

Thierry, Michel. Répertoire des monastères arméniens. Turnhout: Brepols, 1993.

Van Lantschoot, Arn[old]. "Un texte arménien en lettres syriaques." In Mélanges E. Tisserant, vol. 3, Studi e testi 233. Vatican City: Biblioteca Apostolica Vaticana, 1964: 419-428. 
Van Lantschoot, Arn[old]. Inventaire des manuscrits syriaques des fonds Vatican (490-631) Barberini oriental et Neofiti. Vatican City: Biblioteca Apostolica Vaticana, 1965.

Vaschalde (ed.), A. Dionysii Bar Salibi Commentarii in Evangelia, II (1) (textus). Paris 1931, repr. Louvain: Durbecq, 1953.

Vööbus, Arthur. Syrische Kanonessammlungen. I. Westsyrische Originalurkunden. 2 vols. Louvain: Sécretariat du Corpus CSO, 1970.

Zieme, Peter. "An Overview of Garshuni Turkish." In Syriac in Its Multi-Cultural Context, ed. H. Teule, E. Keser-Kayaalp, K. Akalin, N. Doru \& M. S. Toprak. Louvain: Peeters, forthcoming.

Zotenberg, H. Catalogues des manuscrits syriaques et sabéens (mandaïtes) de la Bibliothèque nationale. Paris: Imprimerie nationale, 1874.

Žamagirk', arareal surb ew astuacašnorh t'argmančac'n meroc' Sahakay ew Mesrovpay ew eraneli hayrapetac'n Giwtoy ew Hovhannu Mandakunwoy ew srboyn Nersisi Šnorbalwoyn. Kolkata [Kalkat'a]: Arciw tparani Pōłosi Vijēēnean Kostandinopōlsec'woy, 1848.

"Žamagirk". On the basis of the edition Žamagirk' hayasteayc' S. ekełec 'woy, Vałaršapat 1903" (entered by H. Palanǰian, München 1991; TITUS version by Jost Gippert). 1992-2002. Retrieved 12th January 2014 from http://titus.uni-frankfurt.de /texte/etcs/arm/zamanak/zamant.htm. 


\section{APPENDIX: IMAGES}

Aleppo, Syriac Orthodox Archdiocese 61M, fol. 251r

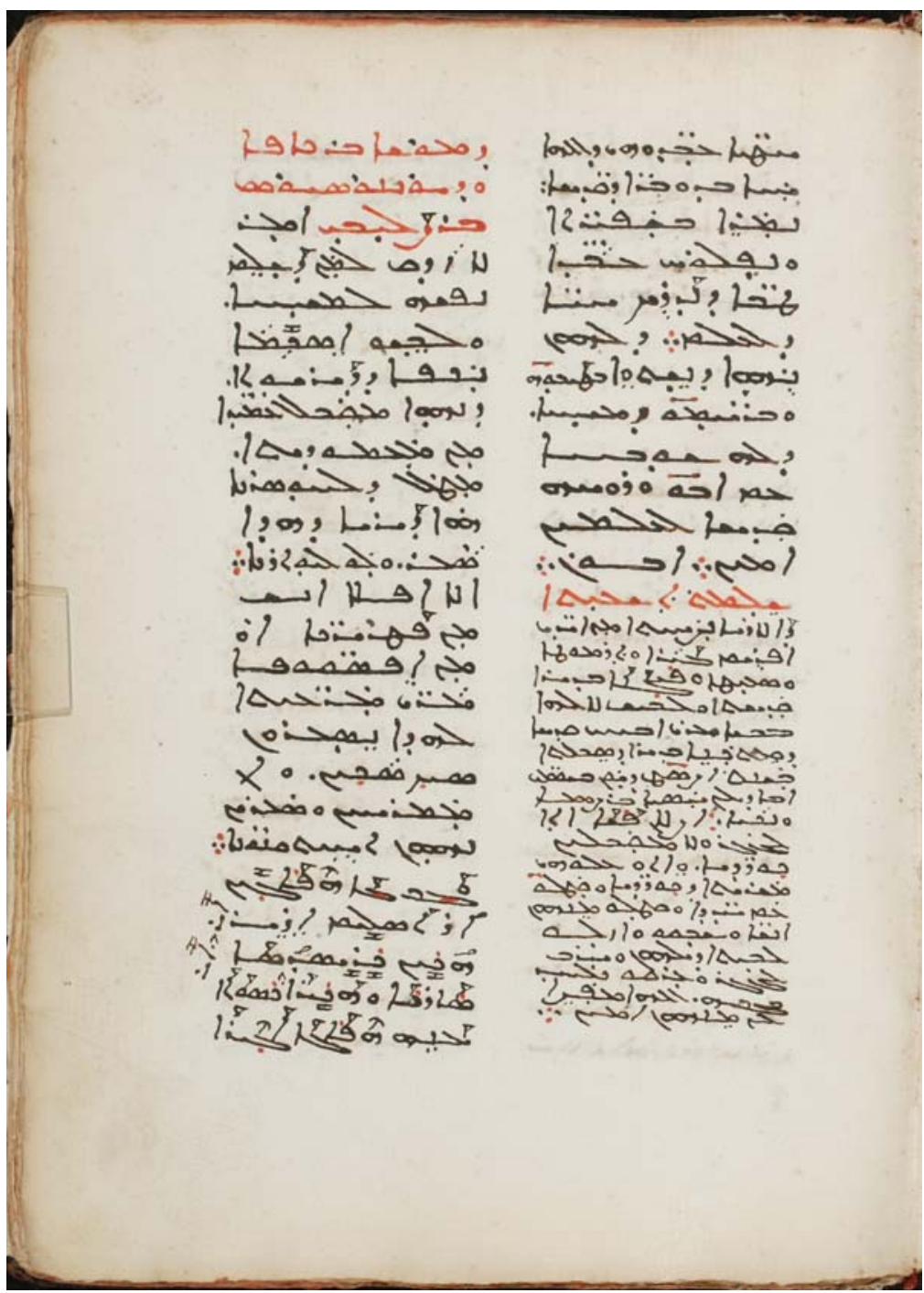

Copyright(C) The Syriac Orthodox Archdiocese of Aleppo and HMML. All rights reserved. 
Aleppo, Syriac Orthodox Archdiocese 61M, fol. 251v

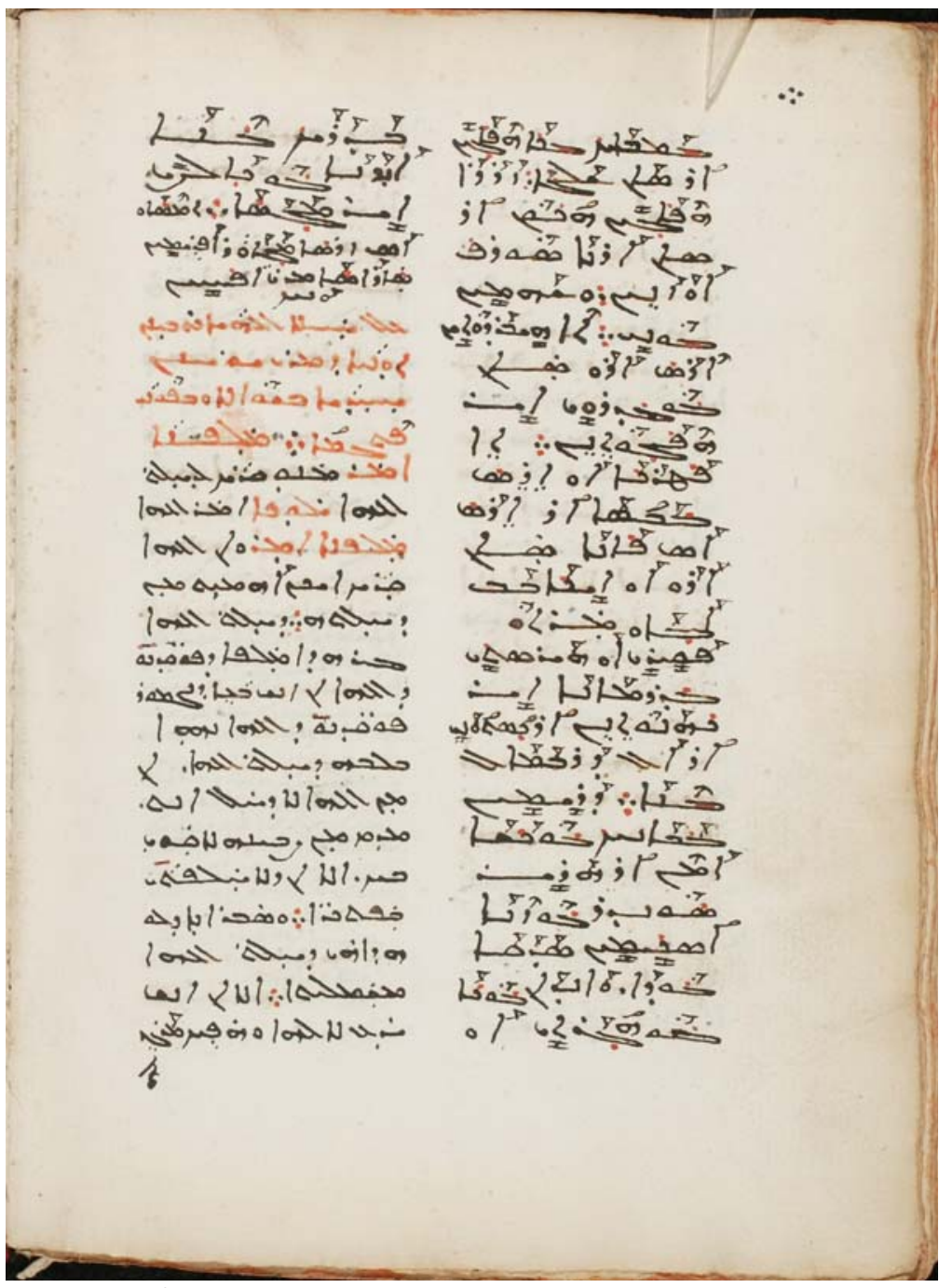

Copyright(C) The Syriac Orthodox Archdiocese of Aleppo and HMML. All rights reserved. 
Mardin, Chaldean Cathedral 10, fol. 8r

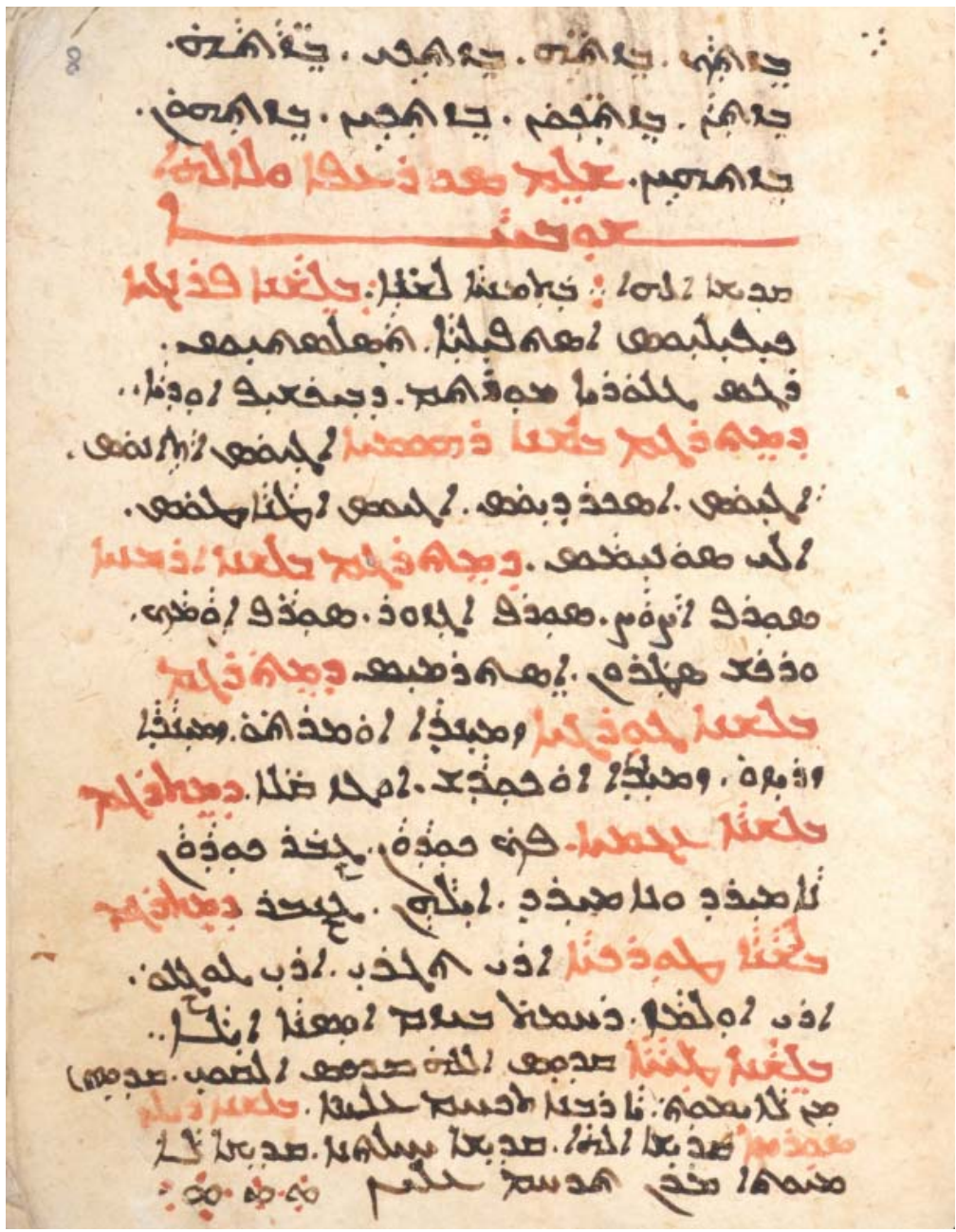

Copyright(C Église Assyro-Chaldéenne de Mardin and HMML. All rights reserved. 
